\title{
Metabolic enzymes that bind RNA: yet another level of cellular regulatory network?
}

\author{
Joanna Cieśla ${ }^{\bowtie}$ \\ Nencki Institute of Experimental Biology, Polish Academy of Sciences, Warszawa, Poland; \\ 凶e-mail: j.ciesla@nencki.gov.pl
}

Received: 03 October, 2005; revised: 15 November, 2005; accepted: 11 January, 2006

available on-line: 12 January, 2006

\begin{abstract}
Several enzymes that were originally characterized to have one defined function in intermediatory metabolism are now shown to participate in a number of other cellular processes. Multifunctional proteins may be crucial for building of the highly complex networks that maintain the function and structure in the eukaryotic cell possessing a relatively low number of proteinencoding genes. One facet of this phenomenon, on which I will focus in this review, is the interaction of metabolic enzymes with RNA. The list of such enzymes known to be associated with RNA is constantly expanding, but the most intriguing question remains unanswered: are the metabolic enzyme-RNA interactions relevant in the regulation of cell metabolism? It has been proposed that metabolic RNA-binding enzymes participate in general regulatory circuits linking a metabolic function to a regulatory mechanism, similar to the situation of the metabolic enzyme aconitase, which also functions as iron-responsive RNA-binding regulatory element. However, some authors have cautioned that some of such enzymes may merely represent "molecular fossils" of the transition from an RNA to a protein world and that the RNA-binding properties may not have a functional significance. Here I will describe enzymes that have been shown to interact with RNA (in several cases a newly discovered RNA-binding protein has been identified as a well-known metabolic enzyme) and particularly point out those whose ability to interact with RNA seems to have a proven physiological significance. I will also try to depict the molecular switch between an enzyme's metabolic and regulatory functions in cases where such a mechanism has been elucidated. For most of these enzymes relations between their enzymatic functions and RNA metabolism are unclear or seem not to exist. All these enzymes are ancient, as judged by their wide distribution, and participate in fundamental biochemical pathways.
\end{abstract}

Keywords: enzymes, mRNA binding, gene expression, translation regulation

One of the methods used most often in detecting direct RNA-protein interaction in vitro is electrophoretic mobility shift assay, in which a complex of radioactively labelled RNA with protein is electophoresed and visualized by autoradiography. The other is filter-binding assay, in which only protein (and protein with bound labelled RNA) binds to the filter that is subsequently measured for ra- dioactivity. To ensure specific RNA-protein interaction, an excess of unlabelled competitor RNA (for example yeast tRNA) is routinely added to the protein prior to incubation with labelled RNA. In some cases to resolve the RNA-protein complex into specific complexes a combination of heparin and RNase $\mathrm{T} 1$ is used. Additionally, to show the specificity of particular RNA-protein interaction, competition ex-

Abbreviations: ARE, AU-rich element; $\mathrm{CKBB}$, creatine kinase brain form B; COLBP, cytochrome $c$ oxidase L-form transcript-binding protein; COX, cytochrome $c$ oxidase; DHFR, dihydrofolate reductase; eALAS, erythroid isoform of 5-aminolevulinate synthase; FdUMP, fluorodeoxyuridine monophosphate; GAPDH, glyceraldehyde-3-phosphate dehydrogenase; $\mathrm{GDH}$, glutamate dehydrogenase; GDK, phosphoglycerate kinase; GM-CSF, granulocyte-macrophage colony-stimulating factor; gRNA, guide RNA; HADHB, hydroxyacyl coenzyme A dehydrogenase/3-ketoacyl-thiolase/enoyl-coenzyme A hydratase (trifunctional protein), $\beta$ subunit; HAV, hepatitis A virus; HBV, hepatitis B virus; HCV, hepatitis C virus; HDV, hepatitis D virus; HPIV, human parainfluenza virus; IDH, isocitrate dehydrogenase; IRES, internal ribosomal entry site; IRE, iron-responsive element; IRF, iron-regulatory factor; IRP, iron-regulatory protein; LDH, lactate dehydrogenase; meTHF, $\mathrm{N}^{5,10-}$ ethylenetetrahydrofolate; MTX, methotrexate; MyHC, myosin heavy chain; RT-PCR, reverse transcription-polymerase chain reaction; SHMT, serine hydroxymethyltransferase; TS, thymidylate synthase; uPAR, urokinase-type plasminogen activator receptor; UTR, untranslated region. 
Table 1. Metabolic enzymes that interact with RNA

\begin{tabular}{|c|c|c|c|}
\hline Enzyme & Catalyzed reaction & Binds & Refrences \\
\hline \multicolumn{4}{|c|}{ Aconitases } \\
\hline $\begin{array}{l}\text { Vertebrate cytoplas- } \\
\text { mic aconitase (IRP1) } \\
\text { E. coli aconitases } \\
\text { Yeast mitochondrial } \\
\text { aconitase (Aco1p) }\end{array}$ & citrate $\rightarrow$ isocitrate & $\begin{array}{l}\text { ferritin mRNA 5'UTR (IRE) } \\
\text { transferrin mRNA 3'UTR (IRE) } \\
\text { ferroportin mRNA 5'UTR (IRE) } \\
\text { DMT-1 mRNA 3'UTR (IRE) } \\
\text { eALAS mRNA 5'UTR (IRE) } \\
\text { m-acon mRNA 5' UTR (IRE) } \\
\text { acnA and acnB mRNA 3'UTR (IRE) }\end{array}$ & $\begin{array}{l}\text { Hentze \& Kuhn, 1996; Hirling et al., } \\
\text { 1994; Klausner et al., } 1993 \text { (reviews); } \\
\text { Abboud \& Haile, 2000; } \\
\text { Gunshin et al., 2001; } \\
\text { Cox et al., 1991; Dandekar et al., 1991; } \\
\text { Kim et al., 1996; } \\
\text { Tang \& Guest, 1999; }\end{array}$ \\
\hline
\end{tabular}

Enzymes involved in glycolysis and the pentose cycle

\begin{tabular}{|c|c|c|c|}
\hline $\begin{array}{l}\text { Glyceraldehyde-3- } \\
\text { phosphate dehydro- } \\
\text { genase (GAPDH) }\end{array}$ & $\begin{array}{l}\text { 3-phosphoglyceralde- } \\
\text { hyde }+\mathrm{NAD}^{+}+\mathrm{P}_{\mathrm{i}} \rightarrow \\
\text { 1,3-diphosphoglyce- } \\
\text { rate + NADH }+\mathrm{H}^{+}\end{array}$ & $\begin{array}{l}\text { tRNA } \\
\text { IFN- } \alpha \text {, c-myc, GM-CSF and IL-2 } \\
\text { mRNA 3'UTR (ARE) } \\
\text { GLUT1 mRNA 3'UTR (ARE) } \\
\text { ribosomal RNA } \\
\text { TNF- } \alpha \text { hammerhead ribozyme } \\
\text { HAV RNA 5'UTR (IRES) } \\
\text { HAV RNA 3'UTR (ARE) and 3'coding } \\
\text { HCV RNA 3'UTR } \\
\text { HBV } \\
\text { HPIV RNA 3'UTR (U-rich) } \\
\text { HDV antigenomic RNA } \\
\text { MyHC mRNA 3'UTR }\end{array}$ & $\begin{array}{l}\text { Singh \& Green, 1993; } \\
\text { Nagy \& Rigby, 1995; Nagy et al., 2000; } \\
\text { McGowan \& Pekala, 1996; } \\
\text { Ryazanov, 1985; } \\
\text { Sioud \& Jespersen, 1996; } \\
\text { Chang et al., 1993; Schultz et al., 1996; } \\
\text { Yi et al., 2000; } \\
\text { Dollenmaier \& Weitz, 2003; } \\
\text { Petrik et al., 1999; } \\
\text { Zang et al., 1998; } \\
\text { De et al., 1996; } \\
\text { Lin et al., 2000a; } \\
\text { Kiri \& Goldspink, 2002; }\end{array}$ \\
\hline Aldolase & $\begin{array}{l}\text { fructose-1,6-bispho- } \\
\text { sphate } \leftrightarrow \text { glyceral- } \\
\text { dehyde-3-phosphate } \\
+ \text { dihydroxyacetone } \\
\text { phosphate }\end{array}$ & MyHC mRNA 3'UTR & Kiri \& Goldspink, 2002; \\
\hline $\begin{array}{l}\text { Lactate dehydroge- } \\
\text { nase (LDH) }\end{array}$ & $\begin{array}{l}\text { lactate }+\mathrm{NAD}^{+} \leftrightarrow \\
\text { pyruvate }+\mathrm{NADH} \\
+\mathrm{H}^{+}\end{array}$ & GM-CSF mRNA 3'UTR (ARE) & Pioli et al., 2002; \\
\hline $\begin{array}{l}\text { Phosphoglycerate } \\
\text { kinase (PGK) }\end{array}$ & $\begin{array}{l}\text { 1,3-diphosphogly- } \\
\text { cerate + ADP } \rightarrow \\
\text { 3-phosphoglycerate } \\
+ \text { ATP }\end{array}$ & uPAR mRNA & Shetty et al., 2004; Shetty \& Idell, 2004; \\
\hline $\begin{array}{l}\text { Glucose 6-phosphate } \\
\text { dehydrogenase } \\
\text { (G6PDH) }\end{array}$ & $\begin{array}{l}\text { glucose-6- } \\
\text { phosphate+NADP } \rightarrow \\
\text { 6-phosphoglucono- } \\
\text { lacton + NADPH }\end{array}$ & GLUT1 mRNA 3'UTR (ARE) & McGowan \& Pekala, 1996; \\
\hline
\end{tabular}

Enzymes connected with the TCA cycle

\begin{tabular}{|c|c|c|c|}
\hline $\begin{array}{l}\text { Glutamate dehydro- } \\
\text { genase }(\mathrm{GDH})\end{array}$ & $\begin{array}{l}\text { L-glutamate }+ \\
\mathrm{NAD}(\mathrm{P})^{+}+\mathrm{H}_{2} \mathrm{O} \leftrightarrow \\
\text { 2-oxoglutarate }+ \\
\mathrm{NH}_{4}^{+}+\mathrm{NAD}(\mathrm{P}) \mathrm{H}\end{array}$ & $\begin{array}{l}\text { cytochrome } c \text { oxidase mRNA } \\
\text { gRNA 3'oligo(U) }\end{array}$ & $\begin{array}{l}\text { Preiss et al., 1993; 1995; } \\
\text { Bringaud et al., 1997; Estevez et al., } \\
\text { 1999; }\end{array}$ \\
\hline $\begin{array}{l}\mathrm{NAD}^{+} \text {-dependent } \\
\text { isocitrate dehydroge- } \\
\text { nase }(\mathrm{IDH})\end{array}$ & $\begin{array}{l}\text { isocitrate }+\mathrm{NAD}^{+} \rightarrow \\
\alpha \text {-ketoglutarate }+ \\
\mathrm{CO}_{2}+\mathrm{NADH}+\mathrm{H}^{+}\end{array}$ & $\begin{array}{l}\text { yeast mitochondrial mRNA } 5{ }^{\prime} \mathrm{UTR} \\
\text { (ARE) }\end{array}$ & $\begin{array}{l}\text { Papadopoulou et al., 1990; Dekker et } \\
\text { al., 1992; Elzinga et al., 1993; de Jong et } \\
\text { al., 2000; Anderson et al., 2002; }\end{array}$ \\
\hline
\end{tabular}


Enzymes connected with fatty acid metabolism

\begin{tabular}{|c|c|c|c|}
\hline Enoyl-CoA hydratase & $\begin{array}{l}\Delta^{2,3} \text {-trans-enoyl-CoA } \\
+\mathrm{H}_{2} \mathrm{O} \rightarrow 3 \text {-hydroxy- } \\
\text { acyl-CoA }\end{array}$ & mRNA 3'UTR (ARE) & $\begin{array}{l}\text { Nakagawa et al., 1995; Nakagawa \& } \\
\text { Moroni, 1997; Brennan et al., 1999; }\end{array}$ \\
\hline $\begin{array}{l}\text { Flesh fly 3-oxoacyl- } \\
\text { CoA thiolase } \\
\text { Human HADHB, } \beta \\
\text { subunit }\end{array}$ & $\begin{array}{l}\text { 3-oxoacyl-CoA + } \\
\text { CoA } \rightarrow \text { acetyl-CoA } \\
+ \text { fatty acyl-CoA } \\
\text { with } 2 \text { fewer carbon } \\
\text { atoms }\end{array}$ & $\begin{array}{l}\text { sarcotoxin IIA mRNA 3'UTR } \\
\text { renin mRNA 3'UTR }\end{array}$ & $\begin{array}{l}\text { Nanbu et al., 1993; } \\
\text { Adams et al., 2003; }\end{array}$ \\
\hline
\end{tabular}

Enzymes involved in thymidylate synthesis cycle

\begin{tabular}{|c|c|c|c|}
\hline $\begin{array}{l}\text { Thymidylate syn- } \\
\text { thase (TS) }\end{array}$ & $\begin{array}{l}\text { Deoxyuridine } \\
\text { monophosphate } \\
+N^{5,10} \text {-methylene- } \\
\text { tetrahydrofolate } \rightarrow \\
\text { deoxythymidine } \\
\text { monophosphate }+ \\
\text { dihydrofolate }\end{array}$ & $\begin{array}{l}\text { TS mRNA } \\
\text { p53 mRNA } \\
c-m y c \text { mRNA } \\
\text { various RNAs }\end{array}$ & $\begin{array}{l}\text { Chu et al., 1991; Cieśla et al., 2005; } \\
\text { Ju et al., 1999; Chu et al., 1999; } \\
\text { Chu et al., 1995; } \\
\text { Chu et al., 1996; Cieśla et al., 2005; }\end{array}$ \\
\hline $\begin{array}{l}\text { Dihydrofolate reduc- } \\
\text { tase (DHFR) }\end{array}$ & $\begin{array}{l}\text { Dihydrofolate }+ \\
\text { NADPH }+\mathrm{H}^{+} \rightarrow \\
\text { tetrahydrofolate }+ \\
\mathrm{NADP}^{+}\end{array}$ & DHFR mRNA & $\begin{array}{l}\text { Chu et al., 1993; Ercikan-Abali et al., } \\
\text { 1997; Tai et al., 2002; 2004; }\end{array}$ \\
\hline $\begin{array}{l}\text { Serine hydroxy- } \\
\text { methyltransferase } \\
\text { (SHMT) }\end{array}$ & $\begin{array}{l}\text { Tetrahydrofolate }+ \\
\text { Ser } \leftrightarrow \text { methylenete- } \\
\text { trahydrofolate + Gly } \\
\text { meTHF } \rightarrow \text { 5-formyl- } \\
\text { THF }\end{array}$ & SHMT mRNA 5'UTR & Liu et al., 2000; \\
\hline
\end{tabular}

Other RNA-binding metabolic enzymes

\begin{tabular}{|c|c|c|c|}
\hline $\begin{array}{l}\text { Uracil phosphoribos- } \\
\text { yltransferase (PyrR) }\end{array}$ & $\begin{array}{l}\text { uracil }+ \text { PRPP } \rightarrow \\
\mathrm{UMP}+\mathrm{PP}_{\mathrm{i}}\end{array}$ & pyr mRNA & $\begin{array}{l}\text { Ghim \& Neuhard, 1994; Turner et al., } \\
\text { 1998; Tomchick et al., 1998; Chander } \\
\text { et al., 2005; }\end{array}$ \\
\hline $\begin{array}{l}\text { Creatine kinase brain } \\
\text { form } B(C K B B)\end{array}$ & $\begin{array}{l}\text { creatine }+ \text { ATP } \rightarrow \\
\text { phosphocreatine }+ \\
\text { ADP }\end{array}$ & aMyHC mRNA 3'UTR & Vracar-Grabar \& Russell, 2004; \\
\hline $\begin{array}{l}\text { Mevalonate kinase } \\
(\mathrm{MVK})\end{array}$ & $\begin{array}{l}\text { mevalonate }+ \text { ATP } \rightarrow \\
\text { mevalonate-5-phos- } \\
\text { phate + ADP }\end{array}$ & $\begin{array}{l}\text { luteinizing hormone receptor mRNA } \\
\text { (polypyrimidine-rich) }\end{array}$ & Nair \& Menon, 2004; \\
\hline Catalase & $2 \mathrm{H}_{2} \mathrm{O}_{2} \rightarrow 2 \mathrm{H}_{2} \mathrm{O}+\mathrm{O}_{2}$ & catalase mRNA 3'UTR & Clerch et al., 1996; \\
\hline
\end{tabular}

Enzymes involved in RNA metabolism displaying RNA-binding activities outside their well-established functions

\begin{tabular}{|c|c|c|c|}
\hline $\begin{array}{l}\text { Aminoacyl-tRNA } \\
\text { synthethases }\end{array}$ & $\begin{array}{l}\text { amino acid }+ \text { tRNA } \\
+\mathrm{ATP} \leftrightarrow \text { aminoacyl- } \\
\mathrm{tRNA}+\mathrm{AMP}+\mathrm{PP}_{\mathrm{n}}\end{array}$ & $\begin{array}{l}\text { various cognate and non-cognate } \\
\text { mRNAs }\end{array}$ & $\begin{array}{l}\text { Springer et al., 1985, 1989; Schray \& } \\
\text { Knippers, 1991; Miseta et al., 1991; }\end{array}$ \\
\hline $\begin{array}{l}\text { Endoribonuclease } \\
\text { (CSP41), homologous } \\
\text { to nucleotide-sugar } \\
\text { epimerases and de- } \\
\text { hydrogenases }\end{array}$ & $\begin{array}{l}\text { ss and ds RNA } \\
\text { cleavage }\end{array}$ & $\begin{array}{l}\text { petD pre-mRNA 3'UTR (stem-loop } \\
\text { and ARE) }\end{array}$ & $\begin{array}{l}\text { Yang et al., 1996; Yang \& Stern, 1997; } \\
\text { Baker et al., 1998; }\end{array}$ \\
\hline
\end{tabular}

pet $D$, chloroplast gene encoding subunit IV of the cytochrome $b_{6} f$ complex; pyr, pyrimidine nucleotide biosynthetic operon. 
periments are conducted with the use of unlabelled RNA that binds the protein and competes with labelled RNA or various unlabelled unrelated RNAs that are unable to compete with the labelled RNA. Dissociation constants $\left(K_{\mathrm{d}}\right)$ for specific RNA-protein interaction are within low picomolar to high nanomolar values, however, only for few RNA-binding enzymes have they been measured.

\section{IRP1/CYTOSOLIC ACONITASE}

The best-studied example of a specific RNAbinding protein - whose interaction with its cognate binding site in mRNA (iron-responsive element, IRE) is regulated in response to metabolic signals - is iron-regulatory protein (IRP), formerly known as iron-regulatory factor (IRF) or IRE-binding protein (IRE-BP) (reviewed by Klausner \& Rouault, 1993; Hentze \& Kuhn, 1996; Rouault, 2002; Cairo et al., 2002).

The iron-responsive element (IRE), forming a hairpin structure, is highly conserved in evolution for any given gene and is remarkably similar among different genes harboring such elements, suggesting precise structural constraints in the binding to IRPs (Henderson et al., 1994). Studies on plant and yeast cells, which lack endogenous IRP activity, indicate that the binding of IRP to the IRE is sufficient to regulate translation without requirement for additional cis-acting sequences or trans-acting factors (Kim et al., 1995), although adjacent non-IRE sequences may affect the function of an IRE (Dickey et al., 1988; Dix et al., 1993).

Actually, two structurally and functionally similar cytoplasmic IRPs (IRP1 and IRP2) modulate stability and translation of mRNA encoding proteins involved in regulation of iron homeostasis, i.e. transferrin receptor (TfR, receptor for cellular iron uptake) and ferritin ( $\mathrm{Ft}$, iron storage protein). IRPs bind with high affinity $\left(K_{\mathrm{d}}=5-50 \mathrm{pM}\right.$; Butt et al., 1996) to IRE in the 3' UTR of TfR mRNA protecting it from degradation and leading to enhanced synthesis of TfR protein. On the other hand, IRPs bind to an IRE in 5' UTR of Ft mRNA causing translational repression and leading to decreased synthesis of Ft protein.

IRP1 was purified from human liver (Rouault et al., 1989) and, after partial peptide sequencing, the cDNA encoding this protein was cloned (Rouault et al., 1990) making it possible to find a significant homology with two eukaryotic mitochondrial aconitases (Hentze \& Argos, 1991). Then, bovine cytosolic aconitase was purified, demonstrated to possess an IRE-binding activity and shown by peptide sequencing to be identical with IRP1 (Kennedy et al., 1992). The mitochondrial enzyme lacks the IRE-binding activity, but it also seems to have an additional func- tion, independent of the enzyme's catalytic activity - it has been found to be associated with mitochondrial DNA and shown to be essential for its maintenance (Chen et al., 2005). IRP1, but not IRP2, can switch between the mRNA-binding and enzymatic activities according to cell iron levels. In iron-replete cells the $[4 \mathrm{Fe}-4 \mathrm{~S}]$ catalytic cluster is assembled, the IRE-binding site is not accesible, and IRP1 displays aconitase activity; in iron-depleted cells the cluster is lacking and IRP1 apoprotein functions as an RNAbinding protein (Constable et al., 1992; Klausner \& Rouault, 1993; Hentze \& Kuhn, 1996). This reversible switch allows aconitase/IRP1 to constantly sense iron levels and adapt them to cell requirements without any appreciable change in protein levels. The state of the [4Fe-4S] cluster is also changed by oxygen species and by ${ }^{\circ} \mathrm{NO}$ generated by endogenous synthases or exogenous donors (reviewed by Drapier, 1997; Hanson \& Leibold, 1999; Cairo \& Pietrangelo, 2000), providing a direct regulatory linkage between iron metabolism and oxidative stress. The cluster's stability also depends on the phosphorylation state of a serine residue required for RNA binding (Brown et al., 2002). The enzymatic function of cytosolic aconitase, which is the product of a gene distinct from that encoding the mitochondrial TCA cycle aconitase, has been well characterised, but its role in the metabolism of the cell is not well understood and remains to be established. According to studies in yeast (Narahari et al., 2000), an iron-mediated conversion of IRP1 to aconitase would have the advantage of increasing the NADPH level, thus providing reducing equivalents helpful in maintaining the redox balance.

In addition to modulating ferritin and transferrin receptor levels, IRP can regulate other IREcontaining mRNAs, encoding proteins closely related to iron utilization (erythroid 5-aminolevulinate synthase, eALAS), uptake (proton-coupled iron transporter, DMT1) and release (ferroportin) (Cox et al., 1991; Dandekar et al., 1991; Abboud \& Haile, 2000; Gunshin et al., 2001). Studies of the aconitase family of proteins in prokaryotes and eukaryotes support the suggestion that IRP may also control the synthesis of proteins that are not direct regulators of iron metabolism, such as mammalian mitochondrial aconitase (Kim et al., 1996; Chen et al., 1997), Escherichia coli aconitases A and B (Tang \& Guest, 1999), Drosophila melanogaster succinate dehydrogenase (Kohler et al., 1995; Gray et al., 1996), and Bacillus subtilis cytochrome oxidase (Alen \& Sonenshein, 1999), all of which contain an IRE or IRE-like element in the mRNA. The results of these studies point to regulatory link between iron and energy metabolism in vertebrates, invertebrates and bacteria.

Recently, Lin and coleagues (2001) discovered that protein levels of the 75-kDa Fe-S subunit of mi- 
tochondrial respiratory chain Complex I were modulated by levels of iron in the cell, whereas mRNA levels were minimally changed. They found that the $5^{\prime}$ UTR of the 75-kDa subunit mRNA contained a novel IRE-like stem-loop sequence. RNA-protein gel shift assays demonstrated that a specific cytoplasmic protein, being neither IRP1 nor IRP2 (IRP3?), bound the novel IRE and that the binding of the protein was affected by the iron status. In addition, ferritin IRE was able to compete for binding with this putative IRP. These results suggest that the $75-\mathrm{kDa} F e-S$ subunit of mitochondrial Complex I may be regulated by a novel IRE-IRP system.

As the numbers of target IRE-containing mRNAs and iron-regulatory proteins seem to be growing, novel IRP-IRE interactions regulating and connecting other essential metabolic pathways are awaiting discovery.

\section{ENZYMES INVOLVED IN GLYCOLYSIS AND THE PENTOSE CYCLE}

Several NAD ${ }^{+}$-dependent dehydrogenases and kinases, among them the glycolytic enzymes glyceraldehyde-3-phosphate dehydrogenase (GAPDH), lactate dehydrogenase (LDH) and phosphoglycerate kinase (PGK), have been shown to bind RNA. Although they were found to bind different RNAs, they share common features associated with this activity. They possess coenzyme binding domains, remarkably similar in three-dimensional structure, consisting of two identical $\beta \alpha \beta$-folds each associated with a mononucleotide-binding surface (Rossmann fold; Rossmann et al., 1975), whose similarity is not due to a highly conserved primary structure, but rather to homology at crucial positions in order to ensure similar folding patterns (Wierenga et al., 1986). It has been shown that (di)nucleotides $\left(\mathrm{NAD}^{+}\right.$, $\mathrm{NADH}, \mathrm{ATP}$ ) can compete with RNA binding. Results of mutational studies showed that the N-terminal 43 amino-acid residues of GAPDH, which correspond to the first mononucleotide-binding domain of the NAD-binding fold, are sufficient to confer RNA-binding (Nagy et al., 2000). Studies on RNAbinding combined with peptide mapping localized RNA-binding to the predicted N-terminal $6.8-\mathrm{kDa}$ peptide, known to be involved in the formation of the $\mathrm{NAD}^{+}$-binding domain of GAPDH (Nagy \& Rigby, 1995). These results suggest an involvement of the (di)nucleotide binding fold in RNA binding. Nagy and coworkers (2000) proposed adding the NAD-binding domain to the list of RNA-binding domains/motifs. Most of RNA-binding proteins that contain a Rossmann fold interact with AU-rich elements (ARE) of mRNA. The ARE elements confer message instability as well as translational sup- pression (Shaw \& Kamen, 1986; reviewed by Espel, 2005). The combination of functionally and structurally different sequence motifs, including AU pentamers and nonamers and other U-rich stretches, determines the ultimate destabilizing ability of each particular ARE. Numerous proteins have been reported to specifically recognize these elements and suggested to play a role in the regulation of stability and translatability of various lymphokine, cytokine and proto-oncogene mRNAs.

\section{Glyceraldehyde-3-phosphate dehydrogenase (GAPDH), lactate dehydrogenase (LDH), aldolase, glucose-6-phosphate dehydrogenase (G6PDH), phosphoglycerate kinase (PGK)}

Glyceraldehyde-3-phosphate dehydrogenase has generally been considered to be a housekeeping protein involved mainly in glycolysis, but a number of studies have indicated that it displays diverse activities (reviewed by Sirover, 1999; Ishitani et al., 2003). The protein can act as a kinase, a tubulinand actin-binding protein, play a role in membrane fusion, and act as a target for nitric oxide (Modun et al., 2000; Mazzola \& Sirover, 2002). It has been shown that GAPDH is overexpressed and translocated to the nucleus during apoptosis (Sunaga et al., 1995). In the growing cells GAPDH can act as uracilDNA-glycosylase and helicase (Meyer-Sigler et al., 1991) and participates in the control of transcription and DNA repair (Ronai, 1993). The enzyme has been shown to cleave RNA (Evguenieva-Hackenberg et al., 2002). GAPDH has been found to bind specifically to sequences critical in the regulation of several mRNAs (see Table 1). These include cis-acting elements important in the stability and translation of mRNA, i.e. AU-rich elements in $3^{\prime}$ UTR sequences of lymphokine mRNAs, regions involved in viral transcription and replication, i.e. 3'UTR sequences involved in RNA-dependent RNA polymerase binding for mRNA synthesis, and 5' UTR sequences involved in HAV replication and functioning as ribosomal recognition sites (IRES, internal ribosome entry site) enabling cap-independent translation initiation (with $K_{\mathrm{d}}=0.2 \mathrm{nM}$; Yi et al., 2000). The enzyme has also been shown to bind with high affinity $\left(K_{\mathrm{d}}=18 \mathrm{nM}\right)$ to several tRNAs in a manner that most likely involves both sequence and structure (Singh \& Green, 1993). The physiological significance of the in vitro studies was confirmed by studies in vivo, including identification of GAPDH/lymphokine mRNA association in polysomes (Nagy \& Rigby, 1995) or the presence of GAPDH in RNP particles in human parainfluenza virus-infected cells (De et al., 1996). The activity of GAPDH as either a glycolytic enzyme or an ARE-binding protein may be regulated by the local concentration of $\mathrm{NAD}^{+}, \mathrm{NADH}$, and ATP in dif- 
ferent subcellular compartments (polysomes, cytosol, and nucleus). The Rossmann fold of GAPDH appears to be reciprocally regulated between its RNAbinding (inactive in glycolysis) and $\mathrm{NAD}^{+}$-binding (active in glycolysis) states in vivo (Nagy \& Rigby, 1995). Alternatively, post-translational modifications (redox or otherwise) might influence the intracellular location of GAPDH as well as differentially regulate its RNA- or $\mathrm{NAD}^{+}$-binding activity. Nagy and Rigby (1995) have found that incubation of GAPDH with the reducing agent 2-mercaptoethanol enhances the binding of both lymphokine 3' UTR and tRNA probes, whereas treatment with an oxidizing agent, diamide, markedly decreases the binding of GAPDH to the IFN- $\alpha$ 3' UTR. On the other hand, Arutyunova and coworkers (2003) have shown that binding of total tRNA to reduced apo-GAPDH is much lower than to the oxidized enzyme form.

Recently, GAPDH and another glycolytic enzyme, aldolase, were identified as proteins complexed with the 3' UTR sequence of myosin heavy chain (MyHC) mRNA (Kiri \& Goldspink, 2002). The authors suggest that both enzymes could be involved in transporting the MyHC mRNA to specific regions and/or anchoring of the message in regions of myosin synthesis by association with the cytoskeletal framework. This hypothesis is supported by studies showing that glycolytic enzymes interact with microtubules (Walsh et al., 1989).

Another glycolytic enzyme, lactate dehydrogenase, is a tetramer that may exist in five forms each consisting of combinations of subunits designated $\mathrm{H}$ (for heart) and $\mathrm{M}$ (for skeletal muscle). LDH-M (the isoenzyme consisting of four identical skeletal muscle type subunits) has been identified as an AREbinding protein interacting with granulocyte-macrophage colony-stimulating factor (GM-CSF) mRNA 3' UTR and mediating ARE-dependent translation (Pioli et al., 2002). The RNA-protein binding in vitro and competition with $\mathrm{NAD}^{+}$was demonstrated using UV cross-linking and nitrocellulose filter binding assays. The latter assay indicated that the binding was ARE-specific, as the affinity of purified LDH for mutant AUGUA GM-CSF mRNA was markedly diminished in comparison with wild-type GM-CSF mRNA $\left(K_{\mathrm{d}}=1879 \mathrm{nM}\right.$ and $501.9 \mathrm{nM}$, respectively). Immunoprecipitation, sucrose density gradient analysis and other data collectively demonstrated that $\mathrm{LDH}$ is a polysome-associated protein localized to this compartment by RNA-protein interactions. Moreover, direct association of LDH with AUF1, another ARE-binding protein, that may play multiple roles in the regulation of mRNA turnover, was demonstrated (reviewed by Dean et al., 2004). One potential model for LDH function is that it provides further specificity for the translation and turnover of certain ARE-containing mRNAs through its direct interaction with both ARE and AUF1 protein. There is also a possibility that LDH may act independently of AUF1 and play a distinct role in mRNA translation and turnover. Although both GAPDH and LDH bind to ARE of GM-CSF mRNA, their roles in posttranscriptional gene regulation seem to be different. LDH, but not GAPDH, intracts with AUF1 and appears to be more specific in its interaction with ARE. In addition, LDH binds to GM-CSF mRNA with greater affinity compared to GAPDH (Pioli et al., 2002).

GAPDH, LDH and an enzyme involved in the pentose cycle, glucose-6-phosphate dehydrogenase (G6PDH), have been shown to specifically bind to various regions of the basal glucose transporter (GLUT1) mRNA 3' UTR (McGowan \& Pekala, 1996). The authors hypothesized that binding of one of the dehydrogenases involved in glucose metabolism could control the GLUT1 mRNA half-life and would provide a rapid mechanism for controlling glucose transport, the rate-limiting step of glucose utilization. Comparison of gel mobility shifts obtained with purified enzymes and GLUT1 mRNA 3' UTR to those obtained using authentic cell extracts indicates that GAPDH and G6PDH may play a role in intact cells.

Phosphoglycerate kinase, like several other glycolytic enzymes, has been shown to possess a wide range of biological activities in addition to its well-characterized role in glycolysis, among them possible regulation of virus transcription through interaction of PGK (and another glycolytic enzyme, enolase) with tubulin (Ogino et al., 2001). Recently, the protein purified from cultured human bronchial epithelial cells that specifically reacted with urokinase-type plasminogen activator receptor (uPAR) mRNA has been identified as PGK (Shetty et al., 2004). Expression of uPAR controls several cellular functions, including epithelial cell adhesion, signalling and mitogenesis, because most of the biological activities of urokinase plasminogen activator (uPA) are dependent on its association with uPAR (Vassali et al., 1991; Chapman, 1997). The uPA action yields plasmin, a serine protease, which has been implicated in the pathogenesis of several lung diseases. PGK expressed in both eukaryotic and prokaryotic cells bound in vitro to the coding region of uPAR mRNA (but not to the ARE of UPAR 3' UTR) as shown by gel mobility and Northwestern assays, and a direct in vivo interaction was confirmed by combined immunoprecipitation-RT-PCR (Shetty et al., 2004). PGK overexpression in cultured cells inhibited cell surface UPAR expression, decreased rate of proliferation and migration of cells most likely through destabilization of uPAR mRNA. Evidence indicate that phosphorylation of PGK may play a major role in regulating its ability to bind uPAR mRNA (Shetty \& Idell, 2004). The physiologic relevance of the con- 
nection between uPAR mRNA decay and glycolysis remains unknown.

\section{ENZYMES CONNECTED WITH THE TCA CYCLE}

\section{Glutamate dehydrogenase (GDH)}

Several subunits of mammalian cytochrome $c$ oxidase (COX) have two tissue-specific isoforms referred to as the L-form (for liver) and $\mathrm{H}$-form (for heart). The $\mathrm{H}$-isotypes are only found in the heart and skeletal muscle and are regulated at the level of transcription, whereas the L-isotypes are present in all tissues, and several observations have suggested that their regulation is likely to occur at the level of mRNA expression. A protein termed COLBP (cytochrome $c$ oxidase L-form transcript-binding protein) has been shown to recognize sequences or structures within the 3' UTRs of transcripts encoding the L-, but not H-forms of COX (subunits VIII and VIIa). Moreover, tissue-specific distribution of COLBP activity paralleled the presence of the liver isopeptides in the mature oxidase complex (Preiss et al., 1993), which indicated that COLBP may mediate the tissue-specific regulation of COX liver isoform mRNA expression, possibly by increasing mRNA stability. COLBP has been identified as mitochondrial matrix glutamate dehydrogenase (GDH) (Preiss \& Lightowlers, 1993; Preiss et al., 1995). Binding of mRNAs for $\mathrm{COX}$ subunits by GDH in vitro was inhibited by GTP and NADH in combination, but not by either alone, and partial inhibition of complex formation was noted in the presence of ADP. Mammalian Lglutamate dehydrogenase, catalyzing the reversible oxidative deamination of glutamate to $\alpha$-ketoglutarate and ammonia, utilizing either $\mathrm{NAD}^{+}$or $\mathrm{NADP}^{+}$, has potential importance in linking several metabolic pathways. It possesses many complex properties, being allosterically regulated by numerous effectors and exhibiting concentration-dependent polymerization from a basic hexameric unit to massive polymers (Fisher, 1985). Immunohistochemical data showed two distinct mitochondrial matrix locations for GDH, one soluble and one membrane-associated (de Duve et al., 1962; Knecht et al., 1986). Scatchard analysis and surface plasmon resonance techniques have shown that only a subset of GDH is able to bind RNA, and this subset was shown to be phosphorylated (Preiss et al., 1995). The mutually exclusive subcellular locations for the nuclear-encoded COX subunit mRNA and GDH seem incompatible with an in vivo interaction and consequently with any role in transcript protection or expression. However, it has been hypothesized that the RNA-binding domain of inner-mitochondrial-membrane-associated GDH may span both membranes at contact sites and function to localize several species of cytosolic mRNA at the mitochondrial periphery, anchoring the translation complex to the mitochondrial surface (Preiss et al., 1995; Lightowlers et al., 1996). In accord, a radiolabelled mRNA transcript was found bound to intact mitochondria (Preiss et al., 1995). However, this interesting hypothesis has not been, to my knowledge, verified by further studies.

Studies in trypanosomes provided two facts confirming the affinity between GDH protein and certain sequences or structures in COX mRNA 3' UTR: i) the 3' UTR of cytochrome oxidase subunit II (COX II) mRNA serves exclusively as a cis guide RNA for the coding region of the COX II mRNA (Golden \& Hajduk, 2005), and ii) mitochondrial GDH from Leishmania tarentolae has been identified as a protein that binds to $3^{\prime}$ oligo(U) of guide RNA (gRNA) (Bringaud et al., 1997). Guide RNAs are small RNAs (40-70 nt), typically transcribed from maxicircle DNA independent of their own cognate mRNA. They are complementary to fragments of mature RNA (Blum et al., 1990; Pollard et al., 1990), whose editing involves the insertion and deletion of uridine residues at multiple sites mainly within their coding regions (reviewed by Benne, 1994; Estevez \& Simpson, 1999; Stuart et al., 2005). Taking into account that GDH may bind UTP in competition with $\mathrm{NADP}(\mathrm{H})$ and that $L$. tarentolae in vitro editing activity was also inhibited by high concentrations of $\mathrm{NADP}(\mathrm{H})$, it was proposed that GDH might be involved in editing reaction and could represent a link between mitochondrial metabolism and RNA editing (Bringaud et al., 1997). However, the results of GDH-knockout experiments in the homologous bloodstream T. brucei suggest that the gRNA-binding properties of GDH may not play a role in RNA editing (Estevez et al., 1999).

Despite the very interesting hypotheses regarding the RNA-binding activities of GDH in mammals and trypanosomes, there is no conclusive proof for a physiological role of these interactions.

\section{$\mathrm{NAD}^{+}$-specific isocitrate dehydrogenase (IDH)}

Another mitochondrial dehydrogenase, $\mathrm{NAD}^{+}$specific isocitrate dehydrogenase, that is proposed to regulate flux through the TCA cycle primarily via a positive allosteric response to AMP (Kornberg \& Pricer, 1951; Hathaway \& Atkinson, 1963), has been demonstrated to bind specifically to $5^{\prime}$ UTRs of the eight major yeast mitochondrial mRNAs, encoding inner membrane-localized components of electron transport chain, including three subunits of cytochrome $c$ oxidase, three subunits of ATP synthase and apocytochrome $b$ (Dekker et al., 1992). Most leader sequences of these transcripts are very long and AU-rich, and are not capped at their $5^{\prime}$ ends. 
Specific protein binding sites are localized in different positions with respect to the start codon, but they share secondary structural features that may direct binding of IDH. Unlike for the dehydrogenases described above, IDH-mRNA complex formation in gel shift assays appeared not to be affected by addition of either substrate, cofactor or allosteric effectors of the enzyme (Elzinga et al., 1993; Anderson et al., 2002); sedimentation experiments, however, have shown that the binding of RNA by IDH is affected by AMP in the presence of isocitrate. The enzymatic activity of IDH has been found to be allosterically inhibited by mRNA (Anderson, et al., 2000) and this inhibition is not prevented by the presence of $\mathrm{NAD}^{+}$(Elzinga et al., 1993; Anderson et al., 2002). In addition, the amino-acid residues identified by sitedirected mutagenesis as necessary for RNA binding by IDH were not important for enzyme activity (Elzinga, 2001). Thus the catalytic and RNA-binding sites seem to be distinct. It is not suprising, since crystallographic analyses of related enzymes (Hurley et al., 1991; Imada et al., 1991) have revealed that the $\mathrm{NAD}^{+}$-binding sites of decarboxylating dehydrogenases lack the classical Rossmann fold.

The relevance of the IDH-RNA interaction in vivo is suggested by studies of de Jong et al. (2000), who showed the rates of mitochondrial translation to be increased 1.5-3-fold in yeast strains lacking IDH as compared to normal yeast strain, in accord with a similar increase of the translation product's turnover. They suggested that IDH may supress translation of mRNAs in the mitochondrial matrix until the transcripts are in the vicinity of mRNAspecific membrane-bound translational activators (Grivell, 1995) and thus ensure correct localization of electron transport chain components. Since AMP modulates IDH enzymatic activity and apparently also IDH association with RNA, mitochondrial levels of AMP may be a primary determinant of both the catalytic function in the tricarboxylic acid cycle and the rates of translation of mitochondrial mRNAs. It seems possible that the interaction of IDH with mitochondrial mRNAs could provide a mechanism for coordinate control of metabolite flux through the TCA cycle and of mitochondrial gene expression at the level of translation.

\section{ENZYMES CONNECTED WITH METABOLISM OF FATTY ACIDS}

\section{Enoyl-CoA hydratase}

The protein termed AUH was originally purified from human brain using affinity chromatography on the AU-rich element (ARE) of interleukin 3, and was found to exhibit enoyl-CoA hydratase activity
(Nakagawa et al., 1995). AUH amino-acid sequence exhibited significant homology to both long- and short-chain rat mitochondrial enoyl-CoA hydratases (Kamijo et al., 1993). The protein was able to bind ARE-containing 3' UTR of GM-CSF mRNA, as shown by Northwestern blot analysis. Recombinant AUH has been shown to bind specifically to ARE-containing mRNA $3^{\prime}$ UTRs in GM-CSF, IL-3, c-fos, c-myc and adenoviral AdIVwt transcripts. However, the primary structure of AUH does not contain either a Rossmann fold-forming sequence or any previously described RNA-binding motifs. RNA-binding analysis of deletion mutants revealed a 20 amino-acid sequence that was necessary and sufficient for RNA binding. A distinctive feature of this segment is that it contains multiple lysine residues which provide a positive charge (Nakagawa \& Moroni, 1997). The crystal structure of human AUH protein revealed the distances between these Lys residues to be similar to those between RNA phosphate groups, suggesting that the so called "lysine comb" may bind to ssRNA (Kurimoto et al., 2001). AUH protein was found to bind to a solid ARE-displaying matrix with retained enzymatic activity, suggesting that the RNA binding domain is different from the catalytic domain (Nakagawa et al., 1995). The 20-amino-acid RNA-binding domain of human $\mathrm{AUH}$, as well as sequences thought to constitute the enzyme's active site, are $100 \%$ conserved in murine AUH. Murine AUH has also been shown to be a bifunctional protein exhibiting enzymatic and RNA-binding activities (Brennan et al., 1999). It has been shown, using Western blot analysis and immunoelectron microscopy, that AUH is located in the mitochondria of mouse cells and therefore allows the possibility that ARE-mediated RNA decay and/or processing mechanisms may also function in this organelle. As an ARE-binding protein that contains intrinsic enoyl-CoA hydratase activity, AUH may provide a link between mitochondrial metabolic pathways and RNA stability.

\section{Thiolase}

In a search for factors that bind to the ARE of flesh fly (Sarcophaga peregrina) defense protein, sarcotoxin IIA mRNA, Nanbu et al. (1993) purified a protein that also had a strong affinity for poly(A), poly $(\mathrm{U})$, and poly $(\mathrm{C})$ and some affinity for $\operatorname{poly}(\mathrm{G})$ and poly(I). These results suggested that the protein may interact with poly-pyrimidine rich regions or the poly(A) tract of RNAs. From the partial amino-acid sequence it was shown that this protein has a striking similarity to rat mitochondrial and peroxisomal thiolases and yeast cytoplasmic thiolase. The protein has been demonstrated to have 3-oxoacyl-thiolase activity (see Table 1) similar to rat mitochondrial thiolase. Moreover, purified rat mitochondria thio- 
lase also had an RNA-binding activity, which suggests that this activity is an intrinsic feature of the thiolase (Nanbu et al., 1993). The effect of the binding of sarcotoxin IIA mRNA by flesh fly thiolase on mRNA stability has not been tested and the possible physiologic role of this interaction has not been, to my knowledge, elucidated.

Hydroxyacyl coenzyme A dehydrogenase/3-ketoacylthiolase/enoyl-coenzyme A hydratase (trifunctional protein), $\beta$ subunit (HADHB)

Renin, secreted by renal juxtaglomerular cells, is rate-limiting in angiotensin II generation and tightly regulated in order to ensure expression appropriate to need. One of the levels of this control is renin mRNA half-life. Although renin mRNA does not contain a classical ARE, an AU-rich region at the very end of the 3' UTR has high homology to a region of Sarcophaga peregrina sarcotoxin IIA mRNA. This 34-nucleotide sequence had a destabilizing effect on a linked reporter gene. Yeast threehybrid screening of a fetal kidney cDNA library, with the renin $3^{\prime}$ UTR as a bait, isolated hydroxyacyl coenzyme A dehydrogenase/3-ketoacyl-thiolase/ enoyl-coenzyme A hydratase (trifunctional protein), $\beta$ subunit (HADHB) as a novel mRNA binding protein. Various gel separation and antibody techniques, as well as use of recombinant HADHB, confirmed this result (Adams et al., 2003). Immunoprecipitation and RT-PCR confirmed association of HADHB with renin mRNA in vivo. Upon decreasing HADHB mRNA with RNAi in renin-expressing human pulmonary adenocarcinoma cells, renin protein and mRNA stability increased, pointing to destabilization of renin mRNA by HADHB. Also the thiolase activity may be important in renin mRNA turnover, since 4-bromocrotonic acid (4-BCA), a specific thiolase inhibitor, reduced binding of cell extract proteins, among them HADHB, to renin $3^{\prime}$ UTR in vitro, and cultured cells treated with 4-BCA had elevated renin protein levels over the course of several hours (Adams et al., 2003). The cleavage of disulphide bonds, that are now regarded rather as switches for protein function than mere structural motifs (Hogg, 2003), might affect the function of certain renin mRNA-binding proteins. Intracellular imaging revealed distinct localization of HADHB to the inner mitochondrial membrane, yet similarly to GDH that binds nuclear-encoded COX subunit mRNA, the data support an ability of HADHB to bind renin mRNA.

Since several other mitochondrial proteins, among them AUH and 3-oxoacyl-CoA thiolase from S. peregrina, can bind mRNA, a novel potential link between mitochondrial processes (such as $\beta$-oxidation) and mRNA metabolism is emerging.

\section{ENZYMES INVOLVED IN THYMIDYLATE SYNTHESIS CYCLE}

All three enzymes involved in thymidylate synthesis cycle, thymidylate synthase (TS), dihydrofolate reductase (DHFR) and serine hydroxymethyltransferase (SHMT) have been shown to bind their own mRNA within the $5^{\prime}$ UTR or/and the coding region of the message and to inhibit the cognate mRNA translation.

TS catalyzes the formation of thymidine monophosphate using the $N^{5,10}$-methylenetetrahydrofolate cofactor (meTHF) as the reductant and donor of one-carbon group. The second product of TS reaction, dihydrofolate, is reduced by an NADPHutilizing enzyme, DHFR, and the resulting tetrahydrofolate is then a substrate for the third member of the cycle, pyridoxal-5'-phosphate-dependent enzyme SHMT which converts it back to meTHF using the serine as the donor of one-carbon group.

The reaction catalyzed by TS is the only de novo source of TMP, a substrate for DNA synthesis. DHFR activity provides the key intermediate in onecarbon transfer reactions and is required for the de novo synthesis of dTMP, purines and certain amino acids, whereas SHMT plays a pivotal role in channeling metabolites between amino-acid and nucleotide metabolism. The levels of all three enzymes increase in proliferating cells, including a variety of tumours, and this increase appears to be regulated at both transcriptional and posttranscriptional levels. ST and DHFR are targets in anticancer therapies, in which analogues of folate or pyrimidine are used to inhibit enzyme activity. Development of resistance to drugs has necessitated the identification of alternate targets and SHMT is strongly considered for the design of specific drugs (Rao et al., 2000).

\section{Thymidylate synthase (TS)}

The RNA-binding activity of thymidylate synthase has been discovered by $\mathrm{Chu}$ and coworkers, who showed, using gel mobility shift assay, that human TS formed a complex with its own mRNA (Chu et al., 1991). Using cell-free rabbit reticulocyte model system they also demonstrated the inhibition of TS mRNA translation by exogenously added TS protein. Addition of a TS substrate (deoxyuridine monophosphate, dUMP) or inhibitor (5-fluorodeoxyuridine monophosphate, FdUMP) prevented both the complex formation and the inhibition of translation by human TS (Chu et al., 1994b). These results and several reports describing elevation in TS enzyme level (not connected with mRNA level increase) after short-term exposure to fluoropyrimidines on in vitro and in vivo models as well as in clinical tumour specimens (Spears et al., 1982; Wash- 
tien, 1984; Swain et al., 1989) prompted the authors to formulate the hypothesis that TS mRNA translation is autoregulated by its own protein end product and that accumulation of FdUMP and dUMP after fluoropyrimidine treatment results in a decrease of the intracellular level of unbound TS, which then results in enhanced TS mRNA translation. This hypothesis has been elaborated in following papers from the same laboratory and summarized in several review articles (Chu \& Allegra, 1996; Schmitz et al., 2001; Liu et al., 2002; Tai et al., 2004b).

Using a series of truncated TS RNAs in gel mobility shift and UV cross-linking assays the sites in human and E. coli TS mRNA molecules responsible for TS protein binding were identified. In human TS mRNA one binding site contained a putative stem-loop structure that incorporated the translational start sequence and another was contained within a 200-nt sequence of the protein-coding region (Chu et al., 1993b; Lin et al., 2000b). In bacterial TS mRNA three sequences (each 200-300 nucleotides long) were indicated as responsible for binding (Voeller at el., 1995).

As far as the RNA-binding site on the enzyme molecule is concerned, the responsible domain(s) has not been fully recognized yet. Site-directed mutagenesis of cysteins on human TS protein together with RNA gel shift and in vitro translation assays have determined that Cys- 180 plays a critical role in mediating RNA recognition (but not in the TS enzymatic activity, since the mutated TS expressed over $80 \%$ of the wild-type enzyme catalytic activity), whereas TS protein mutated in Cys-195 (active site cysteine, crucial for TS catalytic activity) retained the RNA-binding activity (Lin et al., 2003). On the other hand, mutation of homologous active site Cys-146 in bacterial thymidylate synthase made the enzyme unable to bind its own mRNA (Voeller et al., 1995). Recently Voeller et al. (2002) studied the interaction of mRNA with synthetic 17-mer peptides, corresponding to successive sequences of TS, and showed that, for the human enzyme, short peptides at the dimer interface are responsible for mRNA binding. The latter would indicate that mRNA could be bound only by the monomer, and not by the dimer. To prove it, the authors demonstrated that a 50-h dialysis, with the use of a membrane letting only monomers through, allowed about $50 \%$ of the enzyme activity to appear on the other side of the membrane. It should be mentioned that mammalian thymidylate synthase is active as a dimer, as a result of a nonsymmetric arrangement of its identical subunits, both participating (although unequally) in the structure of each of the two active centers (Carreras \& Santi, 1995). That is why the above result should probably be interpreted in terms of a monomer-dimer equilibrium in solution, with great excess of the dimer (we have tested that electrophoretic separation of a large amount of recombinant rat thymidylate synthase under non-denaturing conditions in a polyacrylamide gradient gel did not allow identification of a free monomer; Cieśla and Rode, unpublished).

The results of other studies by the Chu's group showed that repression of thymidylate synthase mRNA translation by exogenously added TS protein in rabbit reticulocyte lysate may be mimicked by an antisense oligonucleotide (Schmitz et al., 1998). However, in parallel, results of other authors were published, concerning the in vivo influence of antisense oligoribonucleotides complementary to the part of human thymidylate synthase mRNA that contains the translation initiation site and appears to be one of the critical elements for the binding by the human enzyme of its own mRNA. Transfection of cells of two human tumour lines (MCF-7 and HeLa) with vectors expressing those antisense oligoribonucleotides did not cause lowering of TS cellular level (DeMoor et al., 1998). Other data, indicating also that results of in vitro studies do not necessarily correspond to in vivo conditions, were published (Kitchens et al., 1999). The results of that work indicated that prolongation of the enzyme protein half-life, resulting from enzyme stabilization, rather than autoregulation by the thymidylate synthase protein of its own translation, is the primary mechanism of TS induction by fluoropyrimidines.

Zhang and Rathod (2002) have recently shown that bifunctional DHFR-TS protein of the protozoan parasite that causes malaria, Plasmodium falciparum, also binds to its own mRNA and inhibits DHFR-TS translation. However, in contrast to the corresponding individual human enzymes, DHFR and TS (Ercikan et al., 1993; Chu et al., 1993a; 1994), this interaction is not impaired by substrates or antimetabolites of either enzyme. Considering a direct correlation between the latter difference in translational regulation of the target enzymes in human and parasitic cells and the selectivity of the antimalarial, antifolate drug WR99210, the authors suggested the antifolate's inability to relieve translational inhibition in parasites as co-responsible for the selectivity. However, this correlation has been questioned recently, since on challenging the parasite's cultures with fluoropyrimidines targeted to thymidylate synthase, as well as with antifolates targeted to DHFR, among them WR99210, at levels close to their respective IC $_{50}$ values, DHFR-TS was found to be upregulated (Nirmalan et al., 2004). Thus, the demonstrated in vitro insensitivity of the DHFR-TS-invoked translational repression to substrates/inhibitors does not seem to affect the expected result in intact cells. Interestingly, also our studies on recombinant thymidylate synthase of another parasite, the nematode Trichinella spiralis, showed the enzyme to bind its own mRNA 
and repress in vitro translation of the mRNA, with neither activity being impaired by dUMP, meTHF or FdUMP (Cieśla et al., 2005). These results prompted our further comparative studies that showed that thymidylate synthases from $T$. spiralis, rat and human bind and inhibit translation of their cognate mRNAs, with both phenomena being not abrogated by the presence of ligands (for comparison of the primary structures of the TSs see: Takeishi et al., 1985; Cieśla et al., 1995; Dąbrowska et al., 2004). However, while the $T$. spiralis thymidylate synthase is capable of both binding and inhibiting translation of its own mRNA, the same enzyme preparation used in the two assays revealed that translation was affected at a considerably lower protein/mRNA molar ratio (in the range 5-20) than was binding $(\geq 1000)$. This finding suggested either the presence in the reticulocyte preparation of a factor strengthening the mRNA-protein interaction or a mechanism whereby thymidylate synthase impaired translation differently than by mRNA binding (e.g. interaction of the enzyme with the ribosome). The fact that TS mRNA binding by TS protein exhibits saturation at a very high protein/mRNA molar ratio (evident also in the Chu's papers, although the authors did not comment on that) indicated that only a small fraction of the enzyme is capable of RNA binding. This points to a possibility of the binding being dependent on some posttranslational modification (Fu et al., 1985; Knirsch \& Clerch, 2001; Haegebarth, 2004) and a lack of a mechanistic relation between the two (mRNA binding and translational repression) phenomena. It should be noted that in view of our results being in agreement with those of Zhang and Rathod (2002), but in striking contrast to those of Chu and coworkers, the model of translational autoregulation of TS expression (Chu et al., 1991) may require a correction.

Further studies on the thymidylate synthase potential to bind RNA, employing immunoprecipitation-RT-PCR technique on an extract from colon cancer cells overexpressing TS protein demonstrated that the protein may in vivo form complexes (with similar affinity) not only with its own mRNA, but also with several other RNAs such as those for cmyc, p53, IFN-induced $15 \mathrm{kDa}$ protein, zinc finger protein 8 , kinesin heavy chain and mitochondrial complete RNA (Chu et al., 1994a; 1996; 1999). TS protein binding to $28 \mathrm{~S}$ and $18 \mathrm{~S}$ ribosomal RNA, albeit with a much lower affinity, may be a result of a physical interaction at the level of polysome (Chu et al., 1996). Much effort has been devoted to investigate two of these cross-interactions, namely the binding of TS protein to c-myc and p53 mRNAs. Using immunoprecipitation-RT-PCR and gel mobility shift assay a 165-nt sequence on c-myc RNA that bound the TS protein was located in the $3^{\prime}$ part of the pro- tein-coding region (Chu et al., 1995). This sequence, similarly to full-length c-myc mRNA, repressed the inhibition of TS mRNA translation by TS protein in rabbit reticulocyte lysate. Similar experiments involving TS protein and p53 mRNA have pointed to a sequence contained within 498 nucleotides in the protein-coding region of the p53 message as the TS protein-binding region (Chu et al., 1999). In in vitro translation system TS protein inhibited p53 mRNA translation. To address the role of this interaction in vivo $\mathrm{Chu}$ and coworkers examined the level of p53 in cells overexpressing TS. They found that the p53 protein was not detectable in human colon cancer and rat hepatoma cell lines overexpressing TS protein. The expression of p53 mRNA was the same in parental and resistant cell lines suggesting that the suppression of p53 expression in TS overexpressing cells was a direct result of a decreased translational efficiency of p53 mRNA (Chu et al., 1999; Ju et al., 1999). The authors suggest that a direct interaction between TS protein and p53 mRNA controls p53 expression in vivo (Ju et al., 1999). On the other hand, Longley et al. (2003) have not observed decreased expression of the p53 protein in any of the studied human cell lines overexpressing TS, which indicates lack of direct regulation of p53 synthesis by TS.

\section{Dihydrofolate reductase (DHFR)}

DHFR, the second enzyme involved in the thymidylate synthesis cycle is critical in maintaining the cellular pool of reduced folates. The intracellular level of DHFR is regulated by concentrations of serum factors, changes in cAMP levels, viral infections, exposure to antimetabolites such as MTX and fluoropyrimidines (Bertino et al., 1963; Kellems et al., 1979; Gudewicz et al., 1981; Schuetz et al., 1988). Alterations in DHFR expression result from gene amplification (Hanggi \& Littlefield, 1976; Kaufman et al., 1979) as well as from both transcriptional (Santiago et al., 1984) and posttranscriptional (Bertino et al., 1965; Cowan et al., 1986) regulatory mechanisms. DHFR levels acutely increase after exposure of malignant cells to the antifolate methotrexate, and are independent of DHFR mRNA level and gene copy number (Domin et al., 1982; Bastow et al., 1984). After transcriptional as well as mRNA stability changes and inhibition of enzyme degradation by MTX were ruled out (Domin et al., 1982), it has been proposed that this phenomenon may result from a translational control mechanism (Bastow et al., 1984). It has been shown using gel mobility shift assay, UV crosslinking and nitrocellulose filter-binding methods that DHFR can bind specifically to its own mRNA (Chu et al., 1993a; Ercikan et al., 1993). Studies with the use of rabbit reticulocyte in vitro translation system have shown that DHFR protein inhibits the trans- 
lation of its own mRNA (Ercikan et al., 1993). Substrates (dihydrofolate and NADPH) or MTX markedly diminished the binding of DHFR protein to its mRNA and released the translation arrest (Chu et al., 1993a; Ercikan-Abali et al., 1997). A model of the autoregulation was proposed: DHFR binds to its cognate mRNA when the metabolic needs of the cell are satisfied or the cell is in a quiescent state, whereas when substrate levels are high and/or an inhibitor is present, DHFR is no longer able to bind to its own mRNA, allowing for translation of new DHFR protein.

To characterize the cis-acting element(s) within DHFR mRNA, a series of truncated transcripts were used in binding experiments. A 100nt sequence within the coding region, containing two putative stem-loop structures, was identified as a binding site (Ercikan-Abali et al., 1997). In vitro and in vivo studies further localized this cis-acting element to an 82-nucleotide sequence (Tai et al., 2004a). In parallel, studies aiming at identification of amino-acid residues involved in the interaction with mRNA were carried out. A site-directed mutagenesis study has pointed to Cys- 6 as being essential, and the Ile-7, Arg-28 and Phe- 34 residues as being important for RNA binding. The fact that catalytically inactive mutant proteins retain their RNA-binding activity has indicated that the catalytic domain is distinct from the RNA-binding one (Tai et al., 2002). It remains unclear as to whether these amino acids interact directly with the RNA or whether they maintain the protein in a conformational state that allows the proper binding domain of the protein to interact with the target mRNA. More recently Skacel et al. (2005) used Chinese hamster ovary cells lacking DHFR, in which wild-type and mutant human DHFR-EGFP fusion proteins were expressed, to functionally identify amino acids essential for the upregulation of DHFR caused by antifolates. The results indicated that the upregulation appeared to be independent of the catalytic activity and of the enzyme's affinity for MTX. Since two of the critical residues (Leu-22 and Ser-118) reside in the NADPH binding pocket and the third (Glu-30) is involved in conformational changes upon the binding of NADPH to DHFR, the NADPH-binding site of the enzyme may be involved in mRNA binding. Skacel et al. (2005) have proposed a new model for translational regulation of DHFR by MTX in which the enzyme exists as at least two conformers: one with bound NADPH, and the other bound to DHFR mRNA. The conformers are in equilibrium and can interconvert. Binding of MTX or dihydrofolate to the DHFR-NADPH complex shifts the equilibrium towards the catalytic function of DHFR, whereas MTX or dihydrofolate binding to the DHFR-mRNA complex leads to a conformational change releasing the mRNA, resulting in resumption of DHFR synthesis.

This model assumes that only fraction of the enzyme, the one being in proper conformation, is able to interact with mRNA. Furthermore, other data indicate that mRNA binding by DHFR is not a sole determinant of the translational upregulation in response to antifolate treatment. Raltitrexed, a relatively weak DHFR inhibitor, is significantly less effective than MTX in abolishing the RNA binding activity (Tai et al., 2002), but it is almost equally effective in causing translational upregulation in cells expressing DHFR-EGFP fusion protein from a transgene (Skacel et al., 2005).

To document in vivo activity, various DHFR sequences contained within the coding region were cloned in the $5^{\prime}$ end of luciferase reporter gene, and transient transfection experiments were performed using human colon cancer RKO cells. In cells transfected with a plasmid containg DHFR mRNA cis-aciting element, the luciferase activity was decreased by $50 \%$ in comparison with cells transfected with umodified luciferase reporter plasmid, but could be restored by treatment of these cells with MTX or siRNA targeting DHFR mRNA (Tai et al., 2004).

It should be noted that DHFR protein may also interact with the translation machinery, as we have found recently that chicken liver DHFR represses the translation of thymidylate synthase mRNA in vitro, although it does not bind to TS mRNA in gel shift assay (Cieśla et al., 2005).

\section{Serine hydroxymethyltransferase (SHMT)}

SHMT is an enzyme that in human exists both in the cytosol (cSHMT) and in mitochondria (mSHMT). Sequence analysis of the respective genes (Stover et al., 1997; Girgis et al., 1998) revealed considerable similarity between the two isoenzymes, although the cytosolic gene was longer than its mitochondrial counterpart. Complete knockout of mSHMT in Saccharomyces cerevisiae leads to glycine auxotrophy, but knocking out of cSHMT does not render the organism auxotrophic for glycine (Kastanos et al., 1997), suggesting different metabolic roles for the two isoenzymes. cSHMT is positioned to play key roles in regulating folate-activated onecarbon metabolism (Girgis et al., 1997). The 5' UTR of cSHMT message is alternatively spliced, creating a full-length $5^{\prime}$ UTR composed of exons 1 and 2 and a shorter UTR that results from excision of exon 2. Both spliced forms have been predicted to form stable stem-loop structures (Girgis et al., 1998), which may indicate tightly regulated protein expression (Byrne et al., 1995). Human CSHMT protein caused inhibition of in vitro translation of luciferase gene with the long or short form of cSHMT $5^{\prime}$ UTR 
fused to the $5^{\prime}$ end. The inhibition was independent of amino acid and folate substrate binding to the cSHMT enzyme. In gel shift experiments the cSHMT protein bound to the 5' UTR of cSHMT mRNA and this interaction was not disturbed by enzyme substrates, either. These results, together with the results of ternary complex absorbance studies and Scatchard analysis, suggest that the catalytic domain of cSHMT and the binding site for mRNA are independent. Additionally, the short form of cSHMT mRNA 5' UTR could effectively inhibit cleavage of allothreonine catalyzed by CSHMT by decreasing $K_{\mathrm{m}}$, which showed that induction of conformational changes in the enzyme by mRNA binding influenced its catalytic properties (Liu et al., 2000). 5Formyltetrahydrofolate (5-formyl-THF), a product of the second reaction catalyzed by cSHMT (see Table 1) is a slow, tight-binding inhibitor of the enzyme (Stover \& Schirch, 1991). 5-Formyl-THF binds to and dissociates quickly from the cSHMT-glycine binary complex when pyridoxal-5'-phosphate is in its external aldimine form. The conversion of the external aldimine to the glycine quinonoid is slow and this step is associated with a conformational change in the enzyme. The off-rate of generation of 5-formylTHF from the cSHMT-glycine-5-formyl-THF ternary complex is rate-limited by the slow conversion of the quinonoid ternary complex to the external aldimine ternary complex. The binding of cSHMT mRNA 5' UTR shifts the equilibrium from the quinonoid ternary complex to the external aldimine ternary complex and thereby permits rapid release of the inhibitor from the enzyme. Therefore, mRNA binding may also play a role in limiting the inhibitory effects of 5-formyl-THF (Liu et al., 2000). However, additional studies are required to determine if cSHMT can regulate its translation in vivo.

Recently Yang and Meier (2003) suggested a novel noncatalytic function for yeast cytosolic hydroxymethyltransferase in cell size control, possibly through the regulation of ribosome biogenesis via a chaperone of small nucleolar ribonucleoprotein particles, Srp40p.

Of interest is the possible connection between folate-dependent one-carbon metabolism and iron metabolism that has been elucidated recently by Oppenheim et al. (2001). The authors have found that human MCF-7 cells expressing rat heavy (but not light) chain ferritin (which is an endogenous chelator influencing free iron regulatory pool) exhibits markedly increased expression of cSHMT. Increased heavy-chain ferritin expression did not alter the cSHMT mRNA level, but it did increase its translation rate and this was mediated, at least in part, through the cSHMT transcript $5^{\prime}$ UTR. It is not clear if heavy-chain ferritin interacts directly with the cSHMT 5' UTR, or if it influences the activity of other mRNA-binding proteins that may be sensitive to decreased intracellular iron concentrations. MCF-7 cells with increased expression of cSHMT displayed increased efficiency of de novo thymidylate biosynthesis, pointing to CSHMT activity as the rate-limiting step of the thymidylate cycle in these cells.

\section{OTHER RNA-BINDING METABOLIC ENZYMES}

\section{PyrR/uracil phosphoribosyltransferase}

The bacterial pyrimidine biosynthetic operon (pyr) encodes all of the enzymes for the de novo biosynthesis of UMP, and two additional cistrons encoding uracil permease and the regulatory protein PyrR (Lerner et al., 1987; Kahler \& Switzer, 1996). In many bacteria PyrR acts by binding to specific sequences on pyr mRNA and causing transcriptional attenuation (Switzer et al., 1999) when intracellular levels of uridine nucleotides are elevated $\left(K_{\mathrm{d}}=10.2 \mathrm{nM}\right.$ at saturating UMP and $216 \mathrm{nM}$ when dUMP was omitted from the binding mixture (Turner et al., 1998)

The uracil phosphoribosyltransferase (UPRTase) activity of PyrR was first discovered by Ghim and Nuehardt (1994), but the protein has little amino-acid sequence resemblance to other bacterial uracil phosphoribosyltransferases and its catalytic activity (see Table 1) is likely to be extremely low under physiological conditions (Turner et al., 1998). The role of the enzymatic function of PyrR is not known; Bacillus subtilis possesses an additional UPRTase that has been shown to be quantitatively more important than PyrR (Martinussen et al., 1995). The crystal structures of $B$. caldolyticus PyrR revealed binding of $\mathrm{Mg}^{2+}$, UMP and GMP and these ligands affected the binding of PyrR to pyr RNA. The binding was enhanced by UMP or UTP, and $\mathrm{Mg}^{2+}$ acted synergistically with either nucleotide to increase the affinity of PyrR for RNA. GMP bound in the UPRTase active site reduced the affinity of the protein for RNA (Chander et al., 2005).

\section{Creatine kinase (CKBB)}

Altered cardiac workload regulates the translation and localization of the $\alpha$ myosin heavy chain $(\alpha \mathrm{MyHC})$ messenger RNA through the 3' UTR by protein-RNA interactions. Gel shift analysis and microsequencing techniques were used to identify the proteins binding to $\alpha \mathrm{MyHC}$ mRNA $3^{\prime}$ UTR from neonatal rat heart (Vracar-Grabar \& Russell, 2004). The proteins were identified as creatine kinase brain $B$ isoform (CKBB), phosphoglycerate kinase (PGK), lactate dehydrogenase (LDH) and fatty acid binding protein (FABP), but Western blotting of the purified proteins and the cytosolic fraction from whole heart 
of neonatal rat preincubated with $\mathrm{MyHC}$ mRNA 3' UTR confirmed only CKBB. LDH, PGK and FABP might be involved in an interaction with $\alpha \mathrm{MyHC}$ mRNA 3' UTR but not directly as binding proteins. They might have a more supportive role than a loosely associated complex with CKBB, further providing a link between different pathways of energetic metabolism and contractile protein synthesis. The authors (Vracar-Grabar \& Russell, 2004) have not found any known consensus RNA binding domains within the $\mathrm{CKBB}$ protein sequence, nonetheless the secondary structure of $\alpha \mathrm{MyHC}$ mRNA 3' UTR revealed a hairpin loop with several bulges that might be potential sites for protein binding. Increasing concentrations of ATP enhanced the interaction of CKBB with $\alpha \mathrm{MyHC}$ mRNA $3^{\prime}$ UTR, suggesting an involvement of CKBB autophosphorylation. The autophosphorylation may depend on $\mathrm{pH}$ and the available levels of ATP, ADP and creatine phosphate important for the primary function of "energy shuffling" in the cell. The finding that CKBB, an energy transduction enzyme, binds to the mRNA 3' UTR of the faster ATP-consuming $\alpha \mathrm{MyHC}$ suggests a possible regulatory linkage between the metabolic state of the cell and myosin isoform expression. Removal of calcium and magnesium ions had a potentiating effect on the formation of CKBB- $\alpha \mathrm{MyHC}$ mRNA 3' UTR complex in vitro, but since CKBB is not itself a calcium binding protein, a simple calcium regulatory mechanism is unlikely.

\section{Mevalonate kinase (MK)}

Luteinizing hormone receptor (LHR) mRNAbinding protein, termed LRBP, has been identified in rat and human ovary (Kash \& Menon, 1999). It bound with high affinity to a polypyrimidine-rich bipartite sequence in the coding region of LHR mRNA. Further studies have demonstrated that in an in vitro reconstituted mRNA decay system, the addition of partially purified LRBP causes accelerated degradation of LHR mRNA (Nair et al., 2002). $\mathrm{N}$-terminal microsequencing, followed by homology search revealed the LRBP identity as mevalonate kinase (MVK). Mevalonate kinase is an enzyme involved in de novo synthesis of cholesterol. In the ovary, the interaction of $\mathrm{LH}$ with $\mathrm{LH}$ receptor is a key event in the regulation of synthesis of steroid hormones from cholesterol (Dufau, 1998). Increased cellular cholesterol inhibits sterol-responsive genes, including key enzymes in cholesterol synthesis (Brown \& Goldstein, 1990). Hence, it is conceivable that under this condition MVK functions as an mRNA-binding protein for the regulation of LHR mRNA levels, leading to the down-regulation of LHR expression. This type of regulation appears to be cell-specific (Kash \& Menon, 1998). The me- valonate kinase LHR mRNA-binding activity was inhibited in the presence of ATP and mevalonate, which indicated that the RNA recognition site of mevalonate kinase might involve the ATP/mevalonate binding region of the protein, or that binding of substrates, ATP and mevalonate, might induce a conformational change in MVK, making it fully functional as a kinase enzyme and rendering it unable to bind to LHR mRNA. Treatment of human embryonic kidney cells with mevastatin (an inhibitor of hydroxymethylglutaryl-CoA reductase that converts hydroxymethylglutaryl-CoA to mevalonate) to deplete cellular mevalonate resulted in an increase in LHR mRNA binding activity of mevalonate kinase. The data support a novel function of rat mevalonate kinase as an LHR mRNA-binding protein in the posttranscriptional regulation of LH-receptor expression in the ovary.

\section{Catalase}

Clerch et al. (1996) have found that NADPHdepleted bovine liver catalase (from Sigma, but not from Calbiochem or Boehringer) binds rat catalase mRNA 3' UTR.

The catalase mRNA 3'UTR cis element involved in the binding is composed of a stem-loop structure and a series of linear CA dinucleotide repeats (Clerch \& Massaro, 1992). The catalase protein/ catalase RNA complex formation was redox-sensitive, inhibited by NADPH and competitively eliminated by a CA dinucleotide repeat (Clerch, 1995). These and other results have indicated that binding of catalase protein to its mRNA involves the dinucleotide binding domain of catalase. Since NADPH is not required for catalase enzymatic activity but serves to protect catalase from inactivation, the authors speculated that NADPH binding to catalase performed an additional function unrelated to its catalytic activity: that is, to regulate the binding of catalase to RNA. Studies aimed at elucidating if these observations have any physiological importance or whether catalase is only a molecular fossil of the RNA world (Kyrpides \& Ouzounis, 1995), have not been, to my knowledge, undertaken.

\section{ENZYMES INVOLVED IN RNA METABOLISM DISPLAYING RNA-BINDING ACTIVITIES OUTSIDE THEIR WELL-ESTABLISHED FUNCTIONS}

\section{Aminoacyl-tRNA synthetases}

Aminoacyl-tRNA synthetases are another example of multifunctional enzymes which, beside 
their primary function of activation of amino acids and transfer to the cognate tRNAs, are involved in many processes such as apoptosis, embryogenesis, synthesis of chlorophil, alarmons $\mathrm{AP}_{4} \mathrm{~A}$, histidine, and also in regulation of gene expression on the level of transcription and translation (reviewed by Ivanov et al., 2000, and by Kamińska et al., 2002).

E. coli threonyl-tRNA synthetase (ThrRS) regulates the translation of its own mRNA by binding to it in a region called the operator, located in front of the ribosomal binding site within the 5' UTR. The primary and secondary structures of the operator resemble those of the anticodon arm of several tRNA $^{\text {Thr }}$ isoacceptor species and are recognized by ThrRS in an analogous way (Springer et al., 1989). The enzyme competes with the $30 \mathrm{~S}$ ribosomal subunit which binds to adjacent translation initiation site. Thus, when the cellular concentration of free synthetase is high, the enzyme binds to threonine synthetase mRNA and competes with and exludes ribosome binding. On the contrary, if the synthetase concentration is low, the ribosome competes effectively with the enzyme and threonine synthetase mRNA is efficiently translated (Springer et al., 1985). Two regions within the synthetase have been identified genetically that are essential to the autoregulation and also are involved in aminoacylation (Springer et al., 1989)

Human glutaminyl-tRNA synthetase (GlnRS) is also able to bind to its own mRNA with affinity comparable to the quantitative estimates for the interaction of several synthetases with their cognate tRNAs $\left(K_{\mathrm{d}}=200 \mathrm{nM}\right.$; Schray \& Knippers, 1991). The enzyme contains two binding regions, one unspecific and the other, responsible for specific binding to a secondary structure RNA element in the $3^{\prime}$ UTR, located in the core region defined as the part of the human enzyme showing high degree of amino-acid sequence similarity with bacterial and yeast synthetases, and therefore considered to be important for the basic enzymatic function. An obvious possibility is that GlnRS recognizes structural features in the mRNA binding site that also occur in tRNA Gln The physiological role of this interaction is unclear. One possibility would be that bound GlnRS induces degradation of mRNA (Schumperli, 1988; Marzluff \& Pandey, 1988).

A protein isolated from polysomal messenger ribonucleoprotein (mRNP) particles from cultured murine erythroleukemia cells was identified as seryl-tRNA synthetase (SerRS). It contains a sequence motif that is shared by both EF- $1 \alpha$ and GlnRS (Miseta et al., 1991). This region in EF-1 $\alpha$ is located between two sequences that are belived to be involved in GTP binding (Brands et al., 1986). Sequences corresponding to the well described RNA-binding protein consensus (Adam et al., 1986) were not found in
SerRS. The results of UV-crosslinking after treatment of cell lysates with edeine, which inhibits the association of $50 \mathrm{~S}$ ribosomal subunits with $48 \mathrm{~S}$ initiation complex, suggest that SerRS may participate directly in the initiation phase of protein synthesis. Given the dimeric structure of SerRS, it could be involved in the association of mRNA with 18S rRNA (Miseta et al., 1991).

It is very likely that more aminoacyl-tRNA synthetases are involved in regulation of gene expression. A role in the initiation phase of protein synthesis has also been suggested for leucyl-tRNA synthetase (Clemens, 1990) and some evidence indicates that Neurospora mitochondrial tyrosyl-tRNA synthetase functions in splicing group I introns (Cherniak et al., 1990).

\section{CSP41/endoribonuclease}

Most chloroplast pre-mRNAs and mature mRNAs contain an inverted repeat sequence in their 3' UTR that can fold into a stable stem-loop structure, which are required for correct 3'-processing of the pre-mRNAs and for stabilization of mature mRNAs, by impeding processive $3^{\prime}$ to $5^{\prime}$ exonucleolytic degradation. Spinach CSP41 protein is part of a protein complex (containing also stem-loop-binding proteins CSP55 and CSP29) that binds to the 3' UTR of petD precursor mRNA, a chloroplast gene encoding subunit IV of the cytochrome $b_{6} / f$ complex (Chen et al., 1995). The RNA-protein complex formation requires not only the stem-loop structure, but also an AU-rich element (box II) immediately upstream of the stem-loop. The CSP41 protein has been purified and nuclear csp41 gene cloned and expressed in bacteria (Yang et al., 1996). Although the aminoacid sequence of CSP41 protein did not show a significant overall similarity to any nuclease in the data bases, it had a substantial nonspecific endoribonuclease activity, degrading both single-stranded and double-stranded RNAs (but not DNAs), with preference for RNAs containing a stable stem-loop structure (Yang \& Stern, 1997). Experimental data suggest that the function of CSP41 could be altered upon interactions with CSP51 and CSP29 (Chen et al., 1995; Yang et al., 1996) by supression of its RNase activity. CSP41 could have two functions in chloroplast mRNA metabolism. First, free CSP41 could directly cleave chloroplast mRNA and pre-mRNA in the $3^{\prime}$ stem-loop structure to initiate bulk mRNA degradation, and second, as CSP41, along with CSP51 and CSP29, forms a stable mRNA-protein complex with the 3' stem-loop structure of pre-mRNA, its RNase activity could be suppressed and the entire complex could serve as a steric hindrance to $3^{\prime}$ to $5^{\prime}$ processive exoribonucleases, and thus ensure efficient $3^{\prime}$ end maturation. Although some RNases have RNA- 
binding activities to target their substrates (Court, 1993), the RNA-binding activity of CSP41 does not enhance the specificity or efficiency of its RNase activity in vitro (Yang \& Stern, 1997), indicating that this RNA-binding activity could be involved in a second function.

\section{CONCLUDING REMARKS}

It is obvious that the list of RNA-binding metabolic enzymes or RNA-binding proteins with intrinsic enzymatic activity is far from being complete. Higher and higher degree of complexity of the metabolic regulatory network is being revealed and well-known proteins with metabolic function established long ago, are now being found to be multifunctional. The relationship between enzymatic functions of proteins described in this paper and their role in gene expression is in most cases unclear and it is likely that it may not exist at all. The switch between those two functions may be triggered by many phenomena, among them the metabolic state of the cell, posttranslational modifications, localization of proteins to different cellular compartments, or intermolecular interactions. All those novel metabolic connections, regulations and mechanisms are awaiting discovery and elucidation.

\section{Acknowledgments}

Supported by the Ministry of Education and Science, Poland (grant number 2 P05A 118 26).

\section{REFERENCES}

Abboud S, Haile DJ (2000) A novel mammalian iron-regulated protein involved in intracellular iron metabolism. J Biol Chem 275: 19906-19912.

Adam SA, Nakagawa T, Swanson MS, Woodruff TK, Dreyfuss G (1986) mRNA polyadenylate-binding protein: gene isolation and sequencing and identification of a ribonucleoprotein consensus sequence. Mol Cell Biol 6: 2932-2943.

Adams DJ, Beveridge DJ, van der Weyden L, Mangs $\mathrm{H}$, Leedman PJ, Morris BJ (2003) HADHB, HuR, and CP1 bind to the distal 3'-untranslated region of human renin mRNA and differentially modulate renin expression. J Biol Chem 278: 44894-44903.

Alen C, Sonenshein AL (1999) Bacillus subtilis aconitase is an RNA-binding protein. Proc Natl Acad Sci USA 96: 10412-10417.

Anderson SL, Minard KI, McAlister-Henn L (2000) Allosteric inhibition of NAD+-specific isocitrate dehydrogenase by a mitochondrial mRNA. Biochemistry 39: 56235629.

Anderson SL, Schirf V, McAlister-Henn L (2002) Effect of $\mathrm{AMP}$ on mRNA binding by yeast $\mathrm{NAD}^{+}$-specific isocitrate dehydrogenase. Biochemistry 41: 7065-7073.

Arutyunova EI, Danshina PV, Domnina LV, Pleten AP, Muronetz VI (2003) Oxidation of glyceraldehyde-3- phosphate dehydrogenase enhances its binding to nucleic acids. Biochem Biophys Res Commun 307: 547-552.

Baker ME, Grundy WN, Elkan CP (1998) Spinach CSP41, an mRNA-binding protein and ribonuclease, is homologous to nucleotide-sugar epimerases and hydroxysteroid dehydrogenases. Biochem Biophys Res Commun 248: 250-254.

Bastow KF, Prabhu R, Cheng YC (1984) The intracellular content of dihydrofolate reductase: possibilities for control and implications for chemotherapy. Adv Enzyme Regul 22: 15-26.

Benne R (1994) RNA editing in trypanosomes. Eur J Biochem 221: 9-23.

Bertino JR, Silber R, Freeman M, Alenty A, Albrecht M, Gabrio BW, Huennekens F (1963) Studies on normal and leukemic leukocytes. IV. Tetrahydrofolate-dependent enzyme systems and dihydrofolic reductase. J Clin Invest 42: 1899-1907.

Bertino JR, Cashmore A, Fink M, Calabresi P, Lefkowitz E (1965) The "induction" of leukocyte and erythrocyte dihydrofolate reductase by methotrexate. II. Clinical and pharmacologic studies. Clin Pharmacol Therap 6: 763-770.

Blum B, Bakalara N, Simpson L (1990) A model for RNA editing in kinetoplastid mitochondria: "guide" RNA molecules transcribed from maxicircle DNA provide the edited information. Cell 60: 189-198.

Brands JH, Maassen JA, van Hemert FJ, Amons R, Moller W (1986) The primary structure of the alpha subunit of human elongation factor 1 . Structural aspects of guanine-nucleotide-binding sites. Eur J Biochem 155: 167-171.

Brennan LE, Nakagawa J, Egger D, Bienz K, Moroni C (1999) Characterisation and mitochondrial localisation of AUH, an AU-specific RNA-binding enoyl-CoA hydratase. Gene 228: 85-91.

Bringaud F, Stripecke R, Frech GC, Freedland S, Turck C, Byrne EM, Simpson L (1997) Mitochondrial glutamate dehydrogenase from Leishmania tarentolae is a guide RNA-binding protein. Mol Cell Biol 17: 3915-3923.

Brown NM, Anderson SA, Steffen DW, Carpenter TB, Kennedy MC, Walden WE, Eisenstein RS (1998) Novel role of phosphorylation in Fe-S cluster stability revealed by phosphomimetic mutations at Ser-138 of iron regulatory protein-1. Proc Natl Acad Sci USA 98: 15235-15240.

Brown MS, Goldstein JL (1990) Regulation of the mevalonate pathway. Nature 343: 425-430.

Butt J, Kim HY, Basilion JP, Cohen S, Iwai K, Philpott CC, Altschul S, Klausner RD, Rouault TA (1996) Differences in the RNA binding sites of iron regulatory proteins and potential target diversity. Proc Natl Acad Sci USA 93: 4345-4349.

Byrne PC, Sanders PG, Snell K (1995) Translational control of mammalian serine hydroxymethyltransferase expression. Biochem Biophys Res Commun 214: 496-502.

Cairo G, Pietrangelo A (2000) Iron regulatory proteins in pathobiology. Biochem J 352: 241-250.

Cairo G, Recalcati S, Pietrangelo A, Minoti G (2002) The iron regulatory proteins: targets and modulators of free radical reactions and oxidative damage. Free Radic Biol Med 32: 1237-1243.

Carreras CW, Santi DV (1995) The catalytic mechanism and structure of thymidylate synthase. Annu Rev Biochem 64: 721-762

Chander P, Halbig KM, Miller JK, Fields CJ, Bonner HK, Grabner GK, Switzer RL, Smith JL (2005) Structure of the nucleotide complex of PyrR, the pyr attenuation protein from Bacillus caldolyticus, suggests dual regula- 
tion by pyrimidine and purine nucleotides. J Bacteriol 187: 1773-1782.

Chang KH, Brown EA, Lemon SM (1993) Cell type-specific proteins which interact with the $5^{\prime}$ nontranslated region of hepatitis A virus RNA. J Virol 67: 6716-6725.

Chapman HA (1997) Plasminogen activators, integrins, and coordinated regulation of cell adhesion and migration. Curr Opin Cell Biol 9: 712-724.

Chen Q, Adams CC, Usack L, Yang J, Monde RA, Stern DB (1995) An AU-rich element in the 3' untranslated region of the spinach chloroplast pet $D$ gene participates in sequence-specific RNA-protein complex formation. Mol Cell Biol 15: 2010-2018.

Chen OS, Schalinske KL, Eisenstein RS (1997) Dietary iron intake modulates the activity of iron regulating proteins (IRPs) and the abundance of ferritin and mitochondrial aconitase in rat liver. J Nutr 127: 238-248.

Chen XJ, Wang X, Kaufman BA, Butow R (2005) Aconitase couples metabolic regulation to mitochondrial DNA maintenance. Science 307: 714-717.

Cherniack AD, Garriga G, Kittle JD Jr, Akins RA, Lambowitz AM (1990) Function of Neurospora mitochondrial tyrosyl-tRNA synthetase in RNA splicing requires an idiosyncratic domain not found in other synthetases. Cell 62: 745-755.

Chu E, Allegra CJ (1996) The role of thymidylate synthase as an RNA binding protein. Bioessays 18: 191-198.

Chu E, Koeller DM, Casey JL, Drake JC, Chabner BA, Elwood PC, Zinn S, Allegra CJ (1991) Autoregulation of human thymidylate synthase messenger RNA translation by thymidylate synthase. Proc Natl Acad Sci USA 88: 8977-8981.

Chu E, Takimoto CH, Voeller D, Grem JL, Allegra CJ (1993a) Specific binding of human dihydrofolate reductase protein to dihydrofolate reductase messenger RNA in vitro. Biochemistry 32: 4756-4760.

Chu E, Voeller D, Koeller DM, Drake JC, Takimoto CH, Maley GF, Maley F, Allegra CJ (1993b) Identification of an RNA binding site for human thymidylate synthase. Proc Natl Acad Sci USA 90: 517-521.

Chu E, Voeller DM, Jones KL, Takechi T, Maley GF, Maley F, Segal S, Allegra CJ (1994a) Identification of a thymidylate synthase ribonucleoprotein complex in human colon cancer cells. Mol Cell Biol 14: 207-213.

Chu E, Voeller DM, Morrison PF, Jones KL, Takechi T, Maley GF, Maley F, Allegra CJ (1994b) The effect of reducing reagents on binding of thymidylate synthase protein to thymidylate synthase messenger RNA. J Biol Chem 269: 20289-20293.

Chu E, Takechi T, Jones KL, Voeller DM, Copur SM, Maley GF, Maley F, Segal S, Allegra CJ (1995) Thymidylate synthase binds to c-myc RNA in human colon cancer cells and in vitro. Mol Cell Biol 15: 179-185.

Chu E, Cogliati T, Copur SM, Borre A, Voeller DM, Allegra CJ, Segal S (1996) Identification of in vivo target RNA sequences bound by thymidylate synthase. $\mathrm{Nu}$ cleic Acids Res 24: 3222-3228.

Chu E, Copur SM, Ju J, Chen TM, Khleif S, Voeller DM, Mizunuma N, Patel M, Maley GF, Maley F, Allegra CJ (1999) Thymidylate synthase protein and p53 mRNA form an in vivo ribonucleoprotein complex. Mol Cell Biol 19: 1582-1594.

Cieśla J, Weiner KX, Weiner RS, Reston JT, Maley GF, Maley $\mathrm{F}$ (1995) Isolation and expression of rat thymidylate synthase cDNA: phylogenetic comparison with human and mouse thymidylate synthases. Biochim Biophys Acta 1261: 233-242.

Cieśla J, Jagielska E, Skopiński T, Dąbrowska M, Maley F, Rode W (2005) Binding and repression of translation of the cognate mRNA by Trichinella spiralis thymidylate synthase differ from the corresponding interactions of the human enzyme. Biochem J 390: 681-688.

Clemens MJ (1990) Does protein phosphorylation play a role in translational control by eukaryotic aminoacyltRNA synthetases? Trends Biochem Sci 15: 172-175.

Clerch LB (1995) A 3' untranslated region of catalase mRNA composed of a stem-loop and dinucleotide repeat elements binds a $69 \mathrm{kDa}$ redox-sensitive protein. Arch Biochem Biophys 317: 267-274.

Clerch LB, Massaro D (1992) Oxidation-reduction-sensitive binding of lung protein to rat catalase mRNA. J Biol Chem 267: 2853-2855.

Clerch LB, Wright A, Massaro D (1996) Dinucleotidebinding site of bovine liver catalase mimics a catalase mRNA-binding protein domain. Am J Physiol 270: L790-L794.

Constable A, Quick S, Gray NK, Hentze MW (1992) Modulation of the RNA-binding activity of a regulatory protein by iron in vitro: switching between enzymatic and genetic function? Proc Natl Acad Sci USA 89: 45544558.

Court D (1993) RNA processing and degradation by RNase III. In Control of Messenger RNA Stability (Belasco JG, Brawerman G, eds) pp 71-116, Academic Press, San Diego.

Cowan KH, Goldsmith ME, Ricciardone MD, Levine R, Rubalcaba E, Jolivet J (1986) Regulation of dihydrofolate reductase in human breast cancer cells and in mutant hamster cells transfected with a human dihydrofolate reductase minigene. Mol Pharmacol 30: 69-76.

Cox TC, Bawden MJ, Martin A, May BK (1991) Human erythroid 5-aminolevulinate synthase: promoter analysis and identification of an iron-responsive element in the mRNA. EMBO J 10: 1891-1902.

Dąbrowska M, Jagielska E, Cieśla J, Płucienniczak A, Kwiatowski J, Wranicz M, Boireau P, Rode W (2004) Trichinella spiralis thymidylate synthase: cDNA cloning and sequencing, and developmental pattern of mRNA expression. Parasitology 128: 209-221.

Dandekar T, Stripecke R, Gray NK, Goossen B, Constable A, Johansson HE, Hentze MW (1991) Identification of a novel iron-responsive element in murine and human erythroid delta-aminolevulinic acid synthase mRNA. EMBO J 10: 1903-1909.

De BP, Gupta S, Zhao H, Drazba JA, Banerjee AK (1996) Specific interaction in vitro and in vivo of glyceraldehyde-3-phosphate dehydrogenase and LA protein with cis-acting RNAs of human parainfluenza virus type 3. J Biol Chem 271: 24728-24735.

de Duve C, Wattiaux R, Baudhuin P (1962) Distribution of enzymes between subcellular fractions in animal tissues. Adv Enzymol 24: 291-358.

de Jong L, Elzinga SD, McCammon MT, Grivell LA, van der Spek H (2000) Increased synthesis and decreased stability of mitochondrial translation products in yeast as a result of loss of mitochondrial $(\mathrm{NAD}(+))$-dependent isocitrate dehydrogenase. FEBS Lett 483: 62-66.

Dean JL, Sully G, Clark AR, Saklatvala J (2004) The involvement of AU-rich element-binding proteins in p38 mitogen-activated protein kinase pathway-mediated mRNA stabilisation. Cell Signal 16: 1113-11321.

Dekker PJ, Stuurman J, van Oosterum K, Grivell LA (1992) Determinants for binding of a $40 \mathrm{kDa}$ protein to the leaders of yeast mitochondrial mRNAs. Nucleic Acids Res 20: 2647-2655.

DeMoor JM, Vincent MD, Collins OM, Koropatnick J (1998) Antisense nucleic acids targeted to the thymidylate 
synthase (TS) mRNA translation start site stimulate TS gene transcription. Exp Cell Res 243: 11-21.

Dickey LF, Wang YH, Shull GE, Wortman IA 3rd, Theil EC (1988) The importance of the 3'-untranslated region in the translational control of ferritin mRNA. J Biol Chem 263: 3071-3074.

Dix DJ, Lin PN, McKenzie AR, Walden WE, Theil EC (1993) The influence of the base-paired flanking region on structure and function of the ferritin mRNA iron regulatory element. J Mol Biol 231: 230-240.

Dollenmaier G, Weitz M (2003) Interaction of glyceraldehyde-3-phosphate dehydrogenase with secondary and tertiary RNA structural elements of the hepatitis A virus $3^{\prime}$ translated and non-translated regions. J Gen Virol 84: 403-414.

Domin BA, Grill SP, Bastow KF, Cheng Y-C (1982) Effect of methotrexate on dihydrofolate reductase activity in methotrexate-resistant human KB cells. Mol Pharmacol 21: $478-482$.

Drapier JC (1997) Interplay between NO and [Fe-S] clusters: relevance to biological systems. Methods 11: 319329.

Dufau ML (1998) The luteinizing hormone receptor. Annu Rev Physiol 60: 461-496.

Elzinga SDJ (2001) PhD Dissertation. University of Amsterdam, The Netherlands.

Elzinga SD, Bednarz AL, van Oosterum K, Dekker PJ, Grivell LA (1993) Yeast mitochondrial NAD(+)-dependent isocitrate dehydrogenase is an RNA-binding protein. Nucleic Acids Res 21: 5328-5331.

Ercikan E, Banerjee D, Waltham M, Schnieders B, Scotto KW, Bertino JR (1993) Translational regulation of the synthesis of dihydrofolate reductase. Adv Exp Med Biol 338: $537-540$.

Ercikan-Abali EA, Banerjee D, Waltham MC, Skacel N, Scotto KW, Bertino JR (1997) Dihydrofolate reductase protein inhibits its own translation by binding to dihydrofolate reductase mRNA sequences within the coding region. Biochemistry 36: 12317-12322.

Espel E (2005) The role of AU-rich elements of mRNAs in controlling translation. Semin Cell Dev Biol 16: 59-67.

Estevez AM, Simpson L (1999) Uridine insertion/deletion RNA editing in trypanosome mitochondria. Gene 240: 247-260.

Estevez AM, Kirszenbaum F, Wirtz E, Bringaud F, Grunstein J, Simpson L (1999) Knockout of the glutamate dehydrogenase gene in bloodstream Trypanosoma brucei cells in culture has no effect on editing of mitochondrial mRNAs. Mol Biochem Parasitol 100: 5-17.

Evguenieva-Hackenberg, Schiltz E, Klug G (2002) Dehydrogenases from all three domains of life cleave RNA. J Biol Chem 277: 46145-46150.

Fisher HF (1985) L-Glutamate dehydrogenase from bovine liver. Methods Enzymol 113: 16-27.

Fu X, Philips N, Jentoft J, Tauzon PT, Traught JA, Leis J (1985) Site-specific phosphorylation of avian retrovirus nucleocapsid protein pp12 regulates binding to viral RNA. Evidence for different protein conformations. $J$ Biol Chem 260: 9941-9947.

Ghim SY, Neuhard J (1994) The pyrimidine biosynthesis operon of the thermophile Bacillus caldolyticus includes genes for uracil phosphoribosyltransferase and uracil permease. J Bacteriol 176: 3698-3707.

Girgis S, Suh JR, Jolivet J, Stover PJ (1997) 5-Formyltetrahydrofolate regulates homocysteine remethylation in human neuroblastoma. J Biol Chem 272: 4729-4734.

Girgis S, Nasrallah IM, Suh JR, Oppenheim E, Zanetti KA, Mastri MG, Stover PJ (1998) Molecular cloning, characterization and alternative splicing of the human cy- toplasmic serine hydroxymethyltransferase gene. Gene 210: 315-324.

Golden DE, Hajduk SL (2005) The 3'-untranslated region of cytochrome oxidase II mRNA functions in RNA editing of African trypanosomes exclusively as a cis guide RNA. RNA 11: 29-37.

Gray NK, Pantopoulos K, Dandekar T, Ackrell B, Hentze MW (1996) Translational regulation of mammalian and Drosophila citric acid cycle enzymes via iron-responsive elements. Proc Natl Acad Sci USA 93: 4925-4930.

Grivell LA (1995) Nucleo-mitochondrial interactions in mitochondrial gene expression. Crit Rev Biochem Mol Biol 30: 121-164.

Gudewicz TM, Morhenn VB, Kellems RE (1981) The effect of polyoma virus, serum factors, and dibutyryl cyclic AMP on dihydrofolate reductase synthesis, and the entry of quiescent cells into S phase. J Cell Physiol 108: $1-8$.

Gunshin H, Allerson CR, Polycarpou-Schwarz M, Rofts A, Rogers JT, Kishi F, Hentze MW, Rouault TA, Andrews NC, Hediger MA (2001) Iron-dependent regulation of the divalent metal ion transporter. FEBS Lett 509: 309316.

Haegebarth A, Heap D, Bie W, Derry JJ, Richard S, Tyner AL (2004) the nuclear tyrosine kinase Brk/Sik phosphorylates and inhibits the RNA-binding activities of the Sam68-like mammalian proteins SLM-1 and SLM-2. J Biol Chem 279: 54398-54404.

Hanggi UJ, Littlefield JW (1976) Altered regulation of the rate of synthesis of dihydrofolate reductase in methotrexate-resistant hamster cells. J Biol Chem 251: 30753080.

Hanson ES, Leibold EA (1999) Regulation of the iron regulatory proteins by reactive nitrogen and oxygen species. Gene Expr 7: 369-376.

Hathaway JA, Atkinson DE (1963) The effect of adenylic acid on yeast nicotinamide adenine dinucleotide isocitrate dehydrogenase, a possible metabolic control mechanism. J Biol Chem 238: 2875-2881.

Henderson BR, Menotti E, Bonnard C, Kuhn LC (1994) Optimal sequence and structure of iron-responsive elements. Selection of RNA stem-loops with high affinity for iron regulatory factor. J Biol Chem 269: 1748117489.

Hentze MW, Argos P (1991) Homology between IRE-BP, a regulatory RNA-binding protein, aconitase, and isopropylmalate isomerase. Nucleic Acids Res 19: 1739-1740.

Hentze MW, Kuhn LC. (1996) Molecular control of vertebrate iron metabolism: mRNA-based regulatory circuits operated by iron, nitric oxide, and oxidative stress. Proc Natl Acad Sci USA 93: 8175-8182.

Hirling H, Henderson BR, Kuhn LC (1994) Mutational analysis of the $[4 \mathrm{Fe}-4 \mathrm{~S}]$-cluster converting iron regulatory factor from its RNA-binding form to cytoplasmic aconitase. EMBO J 13: 453-461.

Hogg PJ (2003) Disulfide bonds as switches for protein function. Trends Biochem Sci 28: 210-214.

Hurley JH, Dean AM, Koshland DE Jr, Stroud RM (1991) Catalytic mechanism of $\mathrm{NADP}(+)$-dependent isocitrate dehydrogenase: implications from the structures of magnesium-isocitrate and NADP+ complexes. Biochemistry 30: 8671-8678.

Imada K, Sato M, Tanaka N, Katsube Y, Matsuura Y, Oshima T (1991) Three-dimensional structure of a highly thermostable enzyme, 3-isopropylmalate dehydrogenase of Thermus thermophilus at $2.2 \AA$ resolution. J Mol Biol 222: 725-738.

Ishitani R, Tajima H, Takata H, Tsuchiya K, Kuwae T, Yamada M, Takahashi H, Tatton NA, Katsube N (2003) 
Proapoptotic protein glyceraldehyde-3-phosphate dehydrogenase: a possible site of action of antiapoptotic drugs. Prog Neuropsychopharmacol Biol Psychiatry 27: 291-301.

Ivanov KA, Moor NA, Lavrik OI (2000) Non-canonical functions of aminoacyl-tRNA synthetases. Biochemistry (Mosc) 65: 888-897.

Ju J, Pedersen-Lane J, Maley F, Chu E (1999) Regulation of p53 expression by thymidylate synthase. Proc Natl Acad Sci USA 96: 3769-3774.

Kahler AE, Switzer RL (1996) Identification of a novel gene of pyrimidine nucleotide biosynthesis, pyrDII, that is required for dihydroorotate dehydrogenase activity in Bacillus subtilis. J Bacteriol 178: 5013-5016.

Kamijo T, Aoyama T, Miyazaki J, Hashimoto T (1993) Molecular cloning of the cDNAs for the subunits of rat mitochondrial fatty acid beta-oxidation multienzyme complex. Structural and functional relationships to other mitochondrial and peroxisomal beta-oxidation enzymes. J Biol Chem 268: 26452-26460.

Kamińska M, Zakrzewska A, Madajka M, Barciszewski J (2002) Participation of aminoacyl-tRNA synthetases in cellular processes. Post Biochem 48: 189-199 (in Polish).

Kash JC, Menon KMJ (1998) Identification of a hormonally regulated luteinizing hormone/human chorionic gonadotropin receptor mRNA binding protein. Increased mRNA binding during receptor down-regulation. J Biol Chem 273: 10658-10664.

Kash JC, Menon KMJ (1999) Sequence-specific binding of a hormonally regulated mRNA binding protein to cytidine-rich sequences in the lutropin receptor open reading frame. Biochemistry 38: 16889-16897.

Kastanos EK, Woldman YY, Appling DR (1997) Role of mitochondrial and cytoplasmic serine hydroxymethyltransferase isozymes in de novo purine synthesis in Saccharomyces cerevisiae. Biochemistry 36: 14956-14964.

Kaufman RJ, Brown PC, Schimke RT (1979) Amplified dihydrofolate reductase genes in unstably methotrexateresistant cells are associated with double minute chromosomes. Proc Natl Acad Sci USA 76: 5669-5673.

Kellems RE, Morhenn VB, Pfendt EA, Alt FW, Schimke RT (1979) Polyoma virus and cyclic AMP-mediated control of dihydrofolate reductase mRNA abundance in methotrexate-resistant mouse fibroblasts. J Biol Chem 254: 309-318.

Kennedy MC, Mende-Mueller L, Blondin GA, Beinert H (1992) Purification and characterization of cytosolic aconitase from beef liver and its relationship to the ironresponsive element-binding protein (IRE-BP). Proc Natl Acad Sci USA 89: 11730-11734.

Kim HY, Klausner RD, Rouault TA (1995) Translational repressor activity is equivalent and is quantitatively predicted by in vitro RNA binding for two iron-responsive element-binding proteins, IRP1 and IRP2. J Biol Chem 270: 4983-4986.

Kim H-Y, LaVaute T, Iwai K, Klausner RD, Rouault TA (1996) Identification of conserved and functional ironresponsive element in the 5 '-untranslated region of mammalian mitochondrial aconitase. J Biol Chem 271: 24226-24230.

Kiri A, Goldspink G (2002) RNA-protein interactions of the 3' untranslated regions of myosin heavy chain transcripts. J Muscle Res Cell Motil 23: 119-129.

Kitchens ME, Forsthoefel AM, Rafique Z, Spencer HT, Berger FG (1999) Ligand-mediated induction of thymidylate synthase occurs by enzyme stabilization. Implications for autoregulation of translation. J Biol Chem 274: 12544-1257.
Klausner RD, Rouault TA (1993) A double life: cytosolic aconitase as a regulatory RNA binding protein. Mol Biol Cell 4: 1-5.

Klausner RD, Rouault TA, Harford JB (1993) Regulating the fate of mRNA: the control of cellular iron metabolism. Cell 72: 19-28.

Knecht E, Martinez-Ramon A, Grisolia S (1986) Electron microscopic localization of glutamate dehydrogenase in rat liver mitochondria by an immunogold procedure and monoclonal and polyclonal antibodies. J Histochem Cytochem 34: 913-922.

Knirsch L, Clerch LB (2001) Tyrosine phosphorylation regulates manganese superoxide dismutase (MnSOD) RNA-binding protein activity and MnSOD protein expression. Biochemistry 40: 7890-7895.

Kohler SA, Henderson BR, Kuhn LC (1995) Succinate dehydrogenase B mRNA of Drosophila melanogaster has a functional iron-responsive element in its 5'-untranslated region. J Biol Chem 270: 30781-3076.

Kornberg A, Pricer WE (1951) Di- and triphosphopyridine nucleotide isocitric dehydrogenases in yeast. J Biol Chem 189: 123-136.

Kurimoto K, Fukai S, Nureki O, Muto Y, Yokoyama S (2001) Crystal structure of human AUH protein, a single-stranded RNA binding homolog of enoyl-CoA hydratase. Structure (Camb) 9: 1253-1263.

Kyrpides NC, Ouzounis CA (1995) Nucleic acid-binding metabolic enzymes: living fossils of stereochemical interactions. J Mol Evol 40: 564-569.

Lerner CG, Stephenson BT, Switzer RL (1987) Structure of the Bacillus subtilis pyrimidine biosynthetic (pyr) gene cluster. J Bacteriol 169: 2202-2206.

Lestienne G, Blanquet P, Grunberg-Manago M (1985) Autogenous control of Escherichia coli threonyl-tRNA synthetase expression in vivo. J Mol Biol 185: 93-104.

Lightowlers RN, Sang AE, Preiss T, Chrzanowska-Lightowlers ZM (1996) Targeting proteins to mitochondria: is there a role for mRNA localization? Biochem Soc Trans 24: 527-531.

Lin SS, Chang SC, Wang YH, Sun CY, Chang MF (2000a) Specific interaction between the hepatitis delta virus RNA and glyceraldehyde 3-phosphate dehydrogenase: an enhancement on ribozyme catalysis. Virology 271: 46-57.

Lin X, Parsels LA, Voeller DM, Allegra CJ, Maley GF, Maley F, Chu E (2000b) Characterization of a cis-acting regulatory element in the protein coding region of thymidylate synthase mRNA. Nucleic Acids Res 28: 13811389.

Lin E, Graziano JH, Freyer GA (2001) Regulation of the 75$\mathrm{kDa}$ subunit of mitochondrial complex I by iron. J Biol Chem 276: 27685-27692.

Lin X, Liu J, Maley F, Chu E (2003) Role of cysteine amino acid residues on the RNA binding activity of human thymidylate synthase. Nucleic Acids Res 31: 4882-4887.

Liu X, Reig B, Nasrallah IM, Stover PJ (2000) Human cytoplasmic serine hydroxymethyltransferase is an mRNA binding protein. Biochemistry 39: 11523-11531.

Liu J, Schmitz JC, Lin X, Tai N, Yan W, Farrell M, Bailly M, Chen T, Chu E (2002) Thymidylate synthase as a translational regulator of cellular gene expression. Biochim Biophys Acta 1587: 174-182.

Longley DB, Latif T, Boyer J, Allen WL, Maxwell PJ, Johnston PG (2003) The interaction of thymidylate synthase expression with p53-regulated signaling pathways in tumor cells. Semin Oncol 30 (Suppl 6): 3-9.

Martinussen J, Glaser P, Andersen PS, Saxild HH (1995) Two genes encoding uracil phosphoribosyltransferase are present in Bacillus subtilis. J Bacteriol 177: 271-274. 
Marzluff WF, Pandey NB (1988) Multiple regulatory steps control histone mRNA concentrations. Trends Biochem Sci 13: 49-52.

Mazzola JL, Sirover MA (2002) Alteration of intracellular structure and function glyceraldehyde-3-phosphate dehydrogenase: a common phenotype of neurodegenerative disorders? Neurotoxicology 23: 603-609.

McGowan K, Pekala PH (1996) Dehydrogenase binding to the 3'-untranslated region of GLUT1 mRNA. Biochem Biophys Res Commun 221: 42-45.

Meyer-Siegler K, Mauro DJ, Seal G, Wurzer J, deRiel JK, Sirover MA (1991) A human nuclear uracil DNA glycosylase is the $37-\mathrm{kDa}$ subunit of glyceraldehyde-3phosphate dehydrogenase. Proc Natl Acad Sci USA 88: 8460-8464.

Miseta A, Woodley CL, Greenberg JR, Slobin LI (1991) Mammalian seryl-tRNA synthetase associates with mRNA in vivo and has homology to elongation factor 1 alpha. J Biol Chem 266: 19158-19161.

Modun B, Morrissey J, Williams P (2000) The staphylococcal transferrin receptor: a glycolytic enzyme with novel functions. Trends Micobiol 8: 231-237.

Nagy E, Rigby WF (1995) Glyceraldehyde-3-phosphate dehydrogenase selectively binds AU-rich RNA in the $\mathrm{NAD}(+)$-binding region (Rossmann fold). J Biol Chem 270: 2755-2763.

Nagy E, Henics T, Eckert M, Miseta A, Lightowlers RN, Kellermayer M (2000) Identification of the NAD(+)binding fold of glyceraldehyde-3-phosphate dehydrogenase as a novel RNA-binding domain. Biochem Biophys Res Commun 275: 253-260.

Nair AK, Menon KMJ (2004) Isolation and characterization of a novel trans-factor for luteinizing hormone receptor mRNA from ovary. J Biol Chem 279: 14937-14944.

Nair AK, Kash JC, Peegel H, Menon KMJ (2002) Post-transcriptional regulation of luteinizing hormone receptor mRNA in the ovary by a novel mRNA-binding protein. J Biol Chem 277: 21468-21473.

Nakagawa J, Moroni C (1997) A 20-amino-acid autonomous RNA-binding domain contained in an enoyl-CoA hydratase. Eur J Biochem 244: 890-899.

Nakagawa J, Waldner H, Meyer-Monard S, Hofsteenge J, Jeno P, Moroni C (1995) AUH, a gene encoding an AU-specific RNA binding protein with intrinsic enoylCoA hydratase activity. Proc Natl Acad Sci USA 92: 2051-2055.

Nanbu R, Kubo T, Hashimoto T, Natori S (1993) Purification of an AU-rich RNA binding protein from Sarcophaga peregrina (flesh fly) and its identification as a Thiolase. J Biochem (Tokyo) 114: 432-437.

Narahari J, Ma R, Wang M, Walden WE (2000) The aconitase function of iron regulatory protein 1 . Genetic studies in yeast implicate its role in iron-mediated redox regulation. J Biol Chem 275: 16227-16234.

Nirmalan N, Sims PF, Hyde JE (2004) Translational up-regulation of antifolate drug targets in the human malaria parasite Plasmodium falciparum upon challenge with inhibitors. Mol Biochem Parasitol 136: 63-70.

Ogino T, Yamadera T, Nonaka T, Imajoh-Omi S, Mizumoto K (2001) Enolase, a cellular glycolytic enzyme, is required for efficient transcription of Sendai virus genome. Biochem Biophys Res Commun 285: 447-455.

Oppenheim EW, Adelman C, Liu X, Stover PJ (2001) Heavy chain ferritin enhances serine hydroxymethyltransferase expression and de novo thymidine biosynthesis. J Biol Chem 276: 19855-19861.

Papadopoulou B, Dekker P, Blom J, Grivell LA (1990) A $40 \mathrm{kd}$ protein binds specifically to the $5^{\prime}$-untranslated regions of yeast mitochondrial mRNAs. EMBO J 9: 4135-4143.

Petrik J, Parker H, Alexander GJ (1999) Human hepatic glyceraldehyde 3-phosphate dehydrogenase binds to the poly(U) tract of the $3^{\prime}$ non-coding region of hepatitis C genomic RNA. J Gen Virol 80: 3109-3113.

Pioli PA, Hamilton BJ, Connolly JE, Brewer G, Rigby WF (2002) Lactate dehydrogenase is an AU-rich elementbinding protein that directly interacts with AUF1. J Biol Chem 277: 35738-35745.

Pollard VW, Rohrer SP, Michelotti EF, Hancock K, Hajduk SL (1990) Organization of minicircle genes for guide RNAs in Trypanosoma brucei. Cell 63: 783-790.

Preiss T, Lightowlers RN (1993) Post-transcriptional regulation of tissue-specific isoforms. A bovine cytosolic RNA-binding protein, COLBP, associates with messenger RNA encoding the liver-form isopeptides of cytochrome $c$ oxidase. J Biol Chem 268: 10659-10667.

Preiss T, Hall GA, Lightowlers RN (1993) Identification of bovine glutamate dehydrogenase as an RNA binding protein. J Biol Chem 268: 24523-24526.

Preiss T, Sang AE, Chrzanowska-Lightowlers ZM (1995) The mRNA-binding protein COLBP is glutamate dehydrogenase. FEBS Lett 367: 291-296.

Rao NA, Talwar R, Savithri HS (2000) Molecular organization, catalytic mechanism and function of serine hydroxymethyltransferase - a potential target for cancer chemotherapy. Int J Biochem Cell Biol 32: 405-416.

Rode W, Cieśla J, Jagielska E, Dąbrowska M, Maley F (2005) Binding and repression of translation of the cognate mRNAs by rat and Trichinella spiralis thymidylate synthases differ from the corresponding interactions of the human enzyme. Chemistry and Biology of Pteridines and Folates. Proceedings of the 13th International Symposium on Pteridines and Folates, Egmond aan Zee, The Netherlands, June 20-24, 2005 (G.J. Peters and G. Jansen eds.) Abstracts p. 62.

Ronai Z (1993) Glycolytic enzymes as DNA binding proteins. Int J Biochem 25: 1073-1076.

Rossmann MG, Liljas A, Brändén C-I, Banaszak LJ. (1975) Evolutionary and structural relationships among dehydrogenases. In The Enzymes. 3rd edn (Boyer PD ed) vol 11A, pp 61-101, Academic Press, London.

Rouault TA, Hentze MW, Haile DJ, Harford JB, Klausner RD (1989) The iron-responsive element binding protein: a method for the affinity purification of a regulatory RNA-binding protein. Proc Natl Acad Sci USA 86: 5768-5772.

Rouault TA, Tang CK, Kaptain S, Burgess WH, Haile DJ, Samaniego F, McBride OW, Harford JB, Klausner RD (1990) Cloning of the cDNA encoding an RNA regulatory protein - the human iron-responsive elementbinding protein. Proc Natl Acad Sci USA 87: 7958-7962.

Rouault TA (2002) Post-transcriptional regulation of human iron metabolism by iron regulatory proteins. Blood Cells Mol Dis 29: 309-314.

Ryazanov AG (1985) Glyceraldehyde-3-phosphate dehydrogenase is one of the three major RNA-binding proteins of rabbit reticulocytes. FEBS Lett 192: 131-134.

Santiago C, Collins M, Johnson LF (1984) In vitro and in vivo analysis of the control of dihydrofolate reductase gene transcription in serum-stimulated mouse fibroblasts. J Cell Physiol 118: 79-86.

Schmitz JC, Agrawal S, Chu E (1998) Repression of human thymidylate synthase mRNA translation by antisense 2'-O-methyl oligoribonucleotides. Antisense Nucleic Acid Drug Development 8: 371-378.

Schmitz JC, Liu J, Lin X, Chen TM, Yan W, Tai N, Gollerkeri A, Chu E (2001) Translational regulation 
as a novel mechanism for the development of cellular drug resistance. Cancer Metastasis Rev 20: 33-41.

Schray B, Knippers R (1991) Binding of human glutaminyltRNA synthetase to a specific site of its mRNA. Nucleic Acids Res 19: 5307-5312.

Schuetz JD, Gorse KM, Goldman ID, Westin EH (1988) Transient inhibition of DNA synthesis by 5-fluorodeoxyuridine leads to overexpression of dihydrofolate reductase with increased frequency of methotrexate resistance. J Biol Chem 263: 7708-7712.

Schultz DE, Hardin CC, Lemon SM (1996) Specific interaction of glyceraldehyde 3-phosphate dehydrogenase with the 5'-nontranslated RNA of hepatitis A virus. J Biol Chem 271: 14134-14142.

Schumperli D (1988) Multilevel regulation of replicationdependent histone genes. Trends Genet 4: 187-191.

Shaw G, Kamen R (1986) A conserved AU sequence from the $3^{\prime}$ untranslated region of GM-CSF mRNA mediates selective mRNA degradation. Cell 46: 659-667.

Shetty S, Idell S (2004) Urokinase receptor mRNA stability involves tyrosine phosphorylation in lung epithelial cells. Am J Respir Cell Mol Biol 30: 69-75.

Shetty S, Muniyappa H, Halady PK, Idell S (2004) Regulation of urokinase receptor expression by phosphoglycerate kinase. Am J Respir Cell Mol Biol 31: 100-106.

Singh R, Green MR (1993) Sequence-specific binding of transfer RNA by glyceraldehyde-3-phosphate dehydrogenase. Science 259: 365-368.

Sioud M, Jespersen L (1996) Enhancement of hammerhead ribozyme catalysis by glyceraldehyde-3-phosphate dehydrogenase. J Mol Biol 257: 775-789.

Sirover MA (1999) New insights into an old protein: the functional diversity of mammalian glyceraldehyde-3phosphate dehydrogenase. Biochim Biophys Acta 1432: 159-184.

Skacel N, Menon LG, Mishra PJ, Peters R, Banerjee D, Bertino JR, Abali EE (2005) Identification of amino acids required for the functional up-regulation of human dihydrofolate reductase protein in response to antifolate treatment. J Biol Chem 280: 22721-22731.

Spears CP, Shahinian AH, Moran RG, Heidelberger C, Corbett TH (1982) In vivo kinetics of thymidylate synthetase inhibition of 5-fluorouracil-sensitive and -resistant murine colon adenocarcinomas. Cancer Res 42: 450-456.

Springer M, Plumbridge JA, Butler JS, Graffe M, Dondon J, Mayaux JF, Fayat G, Lestienne P, Blanquet S, Grunberg-Manago M (1985) Autogenous control of Escherichia coli threonyl-tRNA synthetase expression in vivo. J Mol Biol 185: 93-104.

Springer M, Graffe M, Dondon J, Grunberg-Manago M (1989) tRNA-like structures and gene regulation at the translational level: a case of molecular mimicry in Escherichia coli. EMBO J 8: 2417-2424.

Stover P, Schirch V (1991) 5-Formyltetrahydrofolate polyglutamates are slow tight binding inhibitors of serine hydroxymethyltransferase. J Biol Chem 266: 1543-1550.

Stover PJ, Chen LH, Suh JR, Stover DM, Keyomarsi K, Shane B (1997) Molecular cloning, characterization, and regulation of the human mitochondrial serine hydroxymethyltransferase gene. J Biol Chem 272: 18421848.

Stuart KD, Schnaufer A, Ernst NL, Panigrahi AK (2005) Complex management: RNA editing in trypanosomes. Trends Biochem Sci 30: 97-105.

Sunaga K, Takahashi H, Chuang DM, Ishitani R (1995) Glyceraldehyde-3-phosphate dehydrogenase is overexpressed during apoptotic death of neuronal cultures and is recognized by a monoclonal antibodies against amyloid plagues from Alzheimer's brain. Neurosci Lett 200: 133-136.

Swain SM, Lippman ME, Egan EF, Drake JC, Steinberg SM, Allegra CJ (1989) Fluorouracil and high-dose leucovorin in previously treated patients with metastatic breast cancer. J Clin Oncol 7: 890-899.

Switzer RL, Turner RJ, Lu Y (1999) Regulation of the Bacillus subtilis pyrimidine biosynthetic operon by transcriptional attenuation: control of gene expression by an mRNA-binding protein. Prog Nucleic Acids Res Mol Biol 62: 329-367.

Tai N, Ding Y, Schmitz JC, Chu E (2002) Identification of critical amino acid residues on human dihydrofolate reductase protein that mediate RNA recognition. $\mathrm{Nu}$ cleic Acids Res 30: 4481-4488.

Tai N, Schmitz JC, Chen TM, Chu E (2004a) Characterization of a cis-acting regulatory element in the protein-coding region of human dihydrofolate reductase mRNA. Biochem J 378: 999-1006.

Tai N, Schmitz JC, Liu J, Lin X, Bailly M, Chen TM, Chu E (2004b) Translational autoregulation of thymidylate synthase and dihydrofolate reductase. Front Biosci 9: 2521-2526.

Takeishi K, Kaneda S, Ayusawa D, Shimizu K, Gotoh O, Seno T (1985) Nucleotide sequence of a functional cDNA for human thymidylate synthase. Nucleic Acids Res 13: 2035-2043.

Tang Y, Guest JR (1999) Direct evidence for mRNA binding and post-transcriptional regulation by Escherichia coli aconitases. Microbiology 145: 3069-3079.

Tomchick DR, Turner RJ, Switzer RL, Smith JL (1998) Adaptation of an enzyme to regulatory function: structure of Bacillus subtilis PyrR, a pyr RNA-binding attenuation protein and uracil phosphoribosyltransferase. Structure 6: 337-350.

Turner RJ, Bonner ER, Grabner GK, Switzer RL (1998) Purification and characterization of Bacillus subtilis PyrR, a bifunctional pyr mRNA-binding attenuation protein/uracil phosphoribosyltransferase. J Biol Chem 273: 5932-5938.

Vassalli JD, Sappino AP, Belin D (1991) The plasminogen activator/plasmin system. J Clin Invest 88: 1067-1072.

Voeller DM, Changchien L, Maley GF, Maley F, Takechi T, Turner RE, Montfort WR, Allegra CJ, Chu E (1995) Characterization of a specific interaction between Escherichia coli thymidylate synthase and Escherichia coli thymidylate synthase mRNA. Nucleic Acids Res 23: 869-875.

Voeller DM, Zajac-Kaye M, Fisher RJ, Allegra CJ (2002) The identification of thymidylate synthase peptide domains located in the interface region that bind thymidylate synthase mRNA. Biochem Biophys Res Commun 297: 24-31.

Vracar-Grabar M, Russell B (2004) Creatine kinase is an alpha myosin heavy chain 3'UTR mRNA binding protein. J Muscle Res Cell Motil 25: 397-404.

Walsh JL, Keith TJ, Knull HR (1989) Glycolytic enzyme interactions with tubulin and micotubules. Biochim Biophys Acta 999: 64-70.

Washtien WL (1984) Increased levels of thymidylate synthetase in cells exposed to 5-fluorouracil. Mol Pharmacol 25: 171-177.

Wierenga RK, Terpstra P, Hol WGJ (1986) Prediction of the occurrence of the ADP-binding $\beta \alpha \beta$-fold in proteins, using an amino acid sequence fingerprint. $J \mathrm{Mol}$ Biol 187: 101-107.

Yang J, Stern DB (1997) The spinach chloroplast endoribonuclease CSP41 cleaves the 3'-untranslated region of 
petD mRNA primarily within its terminal stem-loop structure. J Biol Chem 272: 12874-12880.

Yang J, Schuster G, Stern DB (1996) CSP41, a sequencespecific chloroplast mRNA binding protein, is an endoribonuclease. Plant Cell 8: 1409-1420.

Yang Y, Meier UT (2003) Genetic interaction between a chaperone of small nucleolar ribonucleoprotein particles and cytosolic serine hydroxymethyltransferase. $J$ Biol Chem 278: 23553-23560.

Yi M, Schultz DE, Lemon SM (2000) Functional significance of the interaction of hepatitis A virus RNA with glyceraldehyde 3-phosphate dehydrogenase (GAPDH): opposing effects of GAPDH and polypyrimidine tract binding protein on internal ribosome entry site function. J Gen Virol 74: 6459-6468.

Zang WQ, Fieno AM, Grant RA, Yen TS (1998) Identification of glyceraldehyde 3-phosphate dehydrogenase as a cellular protein that binds to the hepatitis B virus posttranscriptional regulatory element. Virology 248: 46-52.

Zhang K, Rathod PK (2002) Divergent regulation of dihydrofolate reductase between malaria parasite and human host. Science 296: 545-547. Erratum in: Science (2002), 297: 1278. 